\title{
Depth investigation of rapid sand filters for drinking water production reveals strong stratification in nitrification biokinetic behavior
}

\author{
Tatari, Karolina; Smets, Barth F.; Albrechtsen, Hans-Jørgen
}

Published in:

Water Research

Link to article, DOI:

10.1016/j.watres.2016.04.073

Publication date:

2016

Document Version

Peer reviewed version

Link back to DTU Orbit

Citation (APA):

Tatari, K., Smets, B. F., \& Albrechtsen, H-J. (2016). Depth investigation of rapid sand filters for drinking water production reveals strong stratification in nitrification biokinetic behavior. Water Research, 101, 402-410. https://doi.org/10.1016/j.watres.2016.04.073

\section{General rights}

Copyright and moral rights for the publications made accessible in the public portal are retained by the authors and/or other copyright owners and it is a condition of accessing publications that users recognise and abide by the legal requirements associated with these rights.

- Users may download and print one copy of any publication from the public portal for the purpose of private study or research.

- You may not further distribute the material or use it for any profit-making activity or commercial gain

- You may freely distribute the URL identifying the publication in the public portal 


\title{
Depth investigation of rapid sand filters for drinking water production reveals strong stratification in nitrification biokinetic behavior
}

\author{
Tatari K.*, Smets B. F. and Albrechtsen H.-J.
}

Department of Environmental Engineering, Technical University of Denmark, Miljøvej 113, 2800

Kgs. Lyngby, Denmark

*Corresponding author:Tel: +45 45251604,E-mail: kaot@env.dtu.dk (K. Tatari)

\section{Abstract}

The biokinetic behavior of $\mathrm{NH}_{4}{ }^{+}$removal was investigated at different depths of a rapid sand filter treating groundwater for drinking water preparation. Filter materials from the top, middle and bottom layers of a full-scale filter were exposed to various controlled $\mathrm{NH}_{4}{ }^{+}$loadings in a continuous-flow lab-scale assay. $\mathrm{NH}_{4}^{+}$removal capacity, estimated from short term loading upshifts, was at least 10 times higher in the top than in the middle and bottom filter layers, consistent with the stratification of Ammonium Oxidizing Bacteria (AOB). AOB density increased consistently with the $\mathrm{NH}_{4}{ }^{+}$removal rate, indicating their primarily role in nitrification under the imposed experimental conditions. The maximum AOB cell specific $\mathrm{NH}_{4}{ }^{+}$removal rate observed in the bottom was at least 3 times lower compared to the top and middle layers. Additionally, a significant up-shift capacity (4.6 and 3.5 times) was displayed from the top and middle layers, but not from the bottom layer at increased loading conditions. Hence, AOB with different physiological responses were active at the different depths. The biokinetic analysis predicted that despite the low $\mathrm{NH}_{4}{ }^{+}$removal capacity at the bottom layer, the entire filter is able to cope with a 4-fold instantaneous loading increase without compromising the effluent $\mathrm{NH}_{4}{ }^{+}$. Ultimately, this filter upshift capacity was limited by the density of AOB and their biokinetic behavior, both of which were strongly stratified.

\section{Keywords}

Groundwater treatment, Ammonium Oxidizing Bacteria, Nitrification capacity, Nitrification kinetics, Loading

\section{Introduction}

Rapid sand filtration is widely used in drinking water production to remove compounds such as $\mathrm{NH}_{4}^{+}, \mathrm{Fe}^{2+}$ and $\mathrm{Mn}^{2+}$, which are typical for anoxic groundwaters. Among these compounds, $\mathrm{Fe}^{2+}$ and $\mathrm{Mn}^{2+}$ are chemically and biologically oxidized to low-solubility oxyhydroxides and are removed by precipitation in the filter, while $\mathrm{NH}_{4}{ }^{+}$is biologically oxidized to $\mathrm{NO}_{3}{ }^{-}$. EU member states must comply with the guideline limit of $0.5 \mathrm{mg} / \mathrm{L} \mathrm{NH}_{4}{ }^{+}$in the water leaving the waterworks (Council Directive 98/93/EC 1998), while stricter limits can be applied by the individual member states e.g. $0.05 \mathrm{mg} / \mathrm{L} \mathrm{NH}_{4}{ }^{+}$in Denmark (Danish Ministry of Environment 2014). Guideline limits for $\mathrm{NH}_{4}^{+}$are set to ensure biological stability in the down-stream distribution network in nonchlorinated systems (Chu et al. 2005), and to control the disinfection residual in chlorinated systems (Zhang et al. 2009). 
Single media filters are typically assumed to be homogeneous due to their frequent backwashing (Uhl and Gimbel 2000). However, recent studies have shown that some filters have heterogeneous flow patterns (Lopato et al. 2013) and stratified biomass distributions even with regular backwashing (Albers et al. 2015, Bai et al. 2013, Feng et al. 2013). Stratification can be the result of changes in the filter material density if mineral precipitates form a persistent coating on the sand grains (Gülay et al. 2014). In this case, the lighter mineral-coated grains accumulate preferentially at the top of the filter after each backwashing. There, they are exposed to higher $\mathrm{NH}_{4}{ }^{+}$loadings compared to the heavier less coated grains, which reside deeper in the filter. Stratification of both nitrifying bacterial density and nitrification activity has, indeed, been observed in samples collected from full-scale filters (de Vet et al. 2009, Kihn et al. 2000, Madoni et al. 2001). The assays used in these works involved strong physical mixing that is likely to detach the microbial activity from the filter material, poorly reflecting the in situ biokinetics. Proper estimation of the in situ biokinetics would maintain the spatial attachment of the biomass, and the associated supposed mass transfer limitations.

Stratification of nitrification activity was also observed in pilot-scale filters (Lee et al. 2014, van den Akker et al. 2008). Specifically, Lee and collaborators investigated filter response to short-term $\mathrm{NH}_{4}{ }^{+}$loading increases, created by increasing either the influent $\mathrm{NH}_{4}{ }^{+}$concentration or the flowrate. No difference was observed between the two increased loading scenarios, and the overall filter capacity was estimated to be 5 times higher than the normal operating loading (Lee et al. 2014). Most of this additional capacity was concentrated in the top $0.15 \mathrm{~m}$, while deeper filter layers exhibited very small additional capacities (Lee et al. 2014). This stratification in activity was solely attributed to the change of Ammonium Oxidizing Bacteria (AOB) density with depth, assuming that AOB have the same biokinetic behavior everywhere in the filter (Lee et al. 2014). The biokinetic behavior itself, however, was not directly examined for stratification with depth.

In the present study, we investigate in detail the previously observed limited nitrification capacity at the bottom layer of a rapid sand filter. We aim to examine whether this stratification in activity is exclusively the result of a decrease in AOB density. Hence, the $\mathrm{NH}_{4}{ }^{+}$removal capacity at different depths of a full-scale filter was investigated by exposing the filter material to a series of controlled loading conditions in an offline continuous-flow assay. Molecular analysis before and after the experiments was used to identify the predominant nitrifiers, and to calculate cell specific $\mathrm{NH}_{4}{ }^{+}$ removal rates at each depth. The activity observations were augmented by a 1-D biofilm model analysis to estimate the kinetic parameters at each depth. Ultimately this analysis aimed to reveal if the $\mathrm{NH}_{4}{ }^{+}$removal biokinetics is also stratified in the filter.

\section{Materials \& Methods}

\subsection{Filter core sampling and depth profiling}

Islevbro (Copenhagen, Denmark) waterworks was selected due to the strong activity stratification observed in previous pilot-scale investigations (Lee et al. 2014). The raw water is abstracted from a deep chalk aquifer and the treatment train consists of an aeration step, followed by a retention tank providing about 20 min contact time for oxidation of $\mathrm{Fe}^{2+}$, and a double filtration step consisting of pre- and after-filters. Pre-filters have a bed of coarse stones (3-6 cm diameter) to retain the formed Fe-hydroxides, while after-filters are designed to biologically remove $\mathrm{NH}_{4}{ }^{+}$. After-filters have an average influent flowrate of $1.73 \times 10^{6} \mathrm{~L} / \mathrm{d}$, an influent concentration of $0.13( \pm 0.04) \mathrm{mg} / \mathrm{L} \mathrm{NH}_{4}{ }^{+}-\mathrm{N}$, a cross sectional area of $18 \mathrm{~m}^{2}$ and are $0.70 \mathrm{~m}$ deep. The hydraulic loading is $4 \mathrm{~m} / \mathrm{h}$ and the filters have been in operation for approx. 30 years without filter material replacement. Nominal grain 
diameter is $1 \mathrm{~mm}$ and after-filters are backwashed every 14 days by air scouring ( $3 \mathrm{~min}$ at $90 \mathrm{~m} / \mathrm{h}$ ) and high water flowrates (10 $\mathrm{min}$ at $25 \mathrm{~m} / \mathrm{h}$ ).

Filter material from one after-filter was core-sampled by inserting and gently removing a plexiglass cylinder ( $1 \mathrm{~m}$ height and $5 \mathrm{~cm}$ inner diameter), closed at the top with a rubber stopper. From the collected $0.50 \mathrm{~m}$ filter material core three depth layers were separated: $0-0.10 \mathrm{~m}$ (top), 0.20-0.30 m (middle) and 0.35-0.50 m (bottom) that were used for the lab-scale $\mathrm{NH}_{4}{ }^{+}$removal investigations. The full-scale filter was core-sampled at 3 randomly selected locations and composite samples were created by mixing filter material from the same depth. Sampling took place approximately midway between two backwash events (day 9 after last backwashing). Additionally, 6 filter material subsamples were segregated every $0.05-0.10 \mathrm{~m}$ from the collected core for molecular quantification of AOB and Ammonium Oxidizing Archaea (AOA). Filter material samples for the $\mathrm{NH}_{4}{ }^{+}$removal investigations were stored wet at $10^{\circ} \mathrm{C}$ for 4 days, while sub-samples for molecular quantification were drained and stored at $-20^{\circ} \mathrm{C}$.

The in situ $\mathrm{NH}_{4}{ }^{+}$profile in the filter was obtained by sampling water at $0.05,0.1,0.15,0.2,0.3$ and $0.4 \mathrm{~m}$ depth during 6 sampling campaigns conducted over 2 filter-run cycles. Stainless steel pipes were fixed in the middle of the filter and were connected to a multi-channel peristaltic pump (110 ACR, Ole Dich) sampling water at a $0.6 \mathrm{~L} / \mathrm{h}$. Water samples were immediately filtered (Sartorius Minisart $0.20 \mu \mathrm{m}$ ), frozen and analyzed for $\mathrm{NH}_{4}{ }^{+}$(Merck Spectroquant test kit 1.14752) within 7 days. The in situ volumetric $\mathrm{NH}_{4}{ }^{+}$loading at each filter depth was calculated as the product of the measured $\mathrm{NH}_{4}{ }^{+}$concentration and the flowrate, normalized for the packed filter material volume of the respective depth section.

\subsection{Quantification of depth specific $\mathrm{NH}_{4}^{+}$removal rates}

Filter material from the three investigated depth layers was exposed to a series of $\mathrm{NH}_{4}{ }^{+}$loading levels in a lab-scale column assay to observe the removal rate at each imposed condition. The assay is described in details elsewhere (Tatari et al. 2013). In brief, it consisted of small (5 cm bed height, $2.6 \mathrm{~cm}$ inner diameter) columns packed with the collected filter material that were operated under continuous flow conditions. Filter material from each depth layer was packed in separate columns and the three columns were operated in parallel. The effluent from each column was recirculated at a high recirculation ratio (50) in order to approximate completely-mixed bulk hydrodynamic conditions (Tatari et al. 2013). Each column was supplied with effluent water from Islevbro waterworks, supplemented with $1 \mathrm{mg} / \mathrm{L} \mathrm{NH}_{4}{ }^{+}-\mathrm{N}$ (as $\mathrm{NH}_{4} \mathrm{Cl}$, Merck chemicals) at an influent flowrate of $0.94 \mathrm{~L} / \mathrm{d}$. Recirculation for each column was at $46.8 \mathrm{~L} / \mathrm{d}$ and the hydraulic loading (influent plus recirculation) was $3.8 \mathrm{~m} / \mathrm{h}$, matching full-scale conditions (Tatari et al. 2013). The resulting volumetric (expressed per volume of packed filter material) loading was $35 \mathrm{~g} \mathrm{NH}_{4}^{+}-\mathrm{N} / \mathrm{m}^{3}$ filter material/d, termed the reference loading. The reference loading was chosen as an equivalent to the full-scale filter loading, based on the initial assumption that complete $\mathrm{NH}_{4}{ }^{+}$removal occurs in the upper $0.40 \mathrm{~m}$ of the filter. The in situ loading at each depth was calculated based on the depth profiles and was compared to the reference loading. The experimental set-up is schematically illustrated in the SI (Figure S1).

The columns were operated at reference loading for 9 days, with intermittent short-term (3 to 5 hours) loading up-shifts (Figure S2 in SI). The loading up-shifts were performed within the first 4 days of operation, and the columns were operated for an additional 5 days to identify growth of nitrifiers. The loading was up-shifted to 88, 175 and $350 \mathrm{~g} \mathrm{NH}_{4}{ }^{+}-\mathrm{N} / \mathrm{m}^{3}$ filter material/d by increasing the influent flowrate to 2.34, 4.68 and $9.36 \mathrm{~L} / \mathrm{d}$ at day 3,4 and 2 of operation, respectively, while maintaining the influent concentration at $1 \mathrm{mg} \mathrm{NH}_{4}{ }^{+}-\mathrm{N} / \mathrm{L}$. Each loading up-shift lasted 3-5 $\mathrm{h}$ to prevent substantial growth of nitrifiers during these short-term perturbations. 
External mass transfer conditions were maintained by keeping a nearly steady total (influent and recirculation stream) hydraulic loading to the columns (Tatari et al. 2013). Experiments were carried out at $10^{\circ} \mathrm{C}$ to mimic the in situ water temperatures. Column influents and effluents were manually sampled and analyzed for $\mathrm{NH}_{4}{ }^{+}$and $\mathrm{NO}_{2}{ }^{-}$(Merck Spectroquant test kits 1.14752 and 1.14776 with detection limits of 0.01 and $0.002 \mathrm{mg}$ N/L respectively). The volumetric removal rate at each loading was calculated from concentration differences multiplied by the influent flowrate and normalized for the volume of packed filter material in the column. The maximum observed $\mathrm{NH}_{4}{ }^{+}$removal rate from each column was termed the $\mathrm{NH}_{4}{ }^{+}$removal capacity and was used to predict the full-scale filter performance as described in section 2.5. At the end of the experiments, filter material from each column was collected and stored at $-20^{\circ} \mathrm{C}$ for molecular quantification.

\subsection{Molecular quantification of total bacteria and nitrifiers}

Total Eubacteria, Nitrospira, AOB and AOA were quantified by real-time quantitative PCR (qPCR). Genomic DNA was extracted in triplicate from $0.5 \mathrm{~g}$ drained-wet filter material before and after the column assays (FastDNA SPIN, MP Biomedicals LLC). The concentration and purity of the extracted DNA were estimated by measuring absorbance at 260 and $280 \mathrm{~nm}$ (NanoDrop Products). A group-specific region on the $16 \mathrm{~S}$ ribosomal-RNA gene (16S-rRNA) was targeted by the primer sets $1055 \mathrm{f}$ and 1392R for Total Eubacteria (Ferris et al. 1996, Lane 1991), and CTO189A/B/C and RT1 for AOB (Nitrosomonas plus Nitrosospira clades) (Hermansson and Lindgren 2001) and Nspra675f and Nspra746r for the Nitrospira genus (Graham et al. 2007). AOB and AOA were additionally quantified at the 6 sub-sampled depths by targeting the ammonia monooxygenase (amoA) functional gene, using the primer sets amoA1f and amoA2r for AOB (Rotthauwe et al. 1997) and amoAF and amoAR for AOA (Francis et al. 2005). The qPCR analyses were conducted in triplicate for each DNA-extract in a Chromo 4 thermocycler operated by the Opticon Monitor 3 software (Bio-Rad). Each qPCR reaction contained $12.5 \mu$ l of $2 \times i Q$ SYBR Green Supermix (Bio-Rad), $500 \mathrm{nM}$ of each primer, DNA template (10 ng) and DNA/RNA-free water (Mol. Bio.) to $25 \mu$ l. The thermal cycling conditions consisted of an initial 5 min denaturation at $95^{\circ} \mathrm{C}$, followed by 40 cycles of $30 \mathrm{~s}$ at $94^{\circ} \mathrm{C}$, primer annealing for $30 \mathrm{~s}$ at $55^{\circ} \mathrm{C}$ for Total Eubacteria, $30 \mathrm{~s}$ at $56^{\circ} \mathrm{C}$ for AOB (16S-rRNA), $40 \mathrm{~s}$ at $55^{\circ} \mathrm{C}$ for AOB (amoA), $30 \mathrm{~s}$ at $64^{\circ} \mathrm{C}$ for Nitrospira, $60 \mathrm{~s}$ at $60^{\circ} \mathrm{C}$ for AOA, and $1 \mathrm{~min}$ extension at $72^{\circ} \mathrm{C}$. After the $40^{\text {th }}$ cycle, a final DNA extension at $72^{\circ} \mathrm{C}$ for $10 \mathrm{~min}$ was performed. A melting curve analysis was run (gradient $0.2^{\circ} \mathrm{C} / \mathrm{s}$, range $70-95^{\circ} \mathrm{C}$ ) to confirm specific amplification (Ririe et al. 1997). The gene copy number was obtained by comparing the cycle threshold values of the sample against a standard curve for each qPCR target. The gene copy numbers were converted to cell density/g drained-wet filter material under the assumption that one bacterial cell contains one 16S-rRNA gene copy (Lee et al. 2006). Volumetric (expressed per volume of packed filter material) densities were calculated by multiplying the cell density/g drained-wet filter material with the drained-wet packed bulk density at each depth. To measure the drained-wet packed bulk density, filter material from each depth was drained by gravity for $10 \mathrm{~min}$ and weighed. The drained-wet packed bulk density was calculated from the drained-wet mass and the volume of the packed filter material in a graduated cylinder (Table S1 in SI).

\subsection{Biofilm model outline}

The experimental observations from the depth specific investigations were interpreted by a mathematical model to estimate the kinetic parameters at each depth layer. A model for each labscale column was implemented in Aquasim (Reichert 1998) and conceptually considered reaction and mass transfer at the biofilm scale, and calculated the effluent $\mathrm{NH}_{4}{ }^{+}$and $\mathrm{NO}_{2}{ }^{-}$concentrations by mass balances at the macro-scale. The biofilm on the surface of spherical filter material grains was considered continuous and homogeneous. 
Nitrification was modeled as a two-step reaction: $\mathrm{NH}_{4}{ }^{+}$oxidation to $\mathrm{NO}_{2}^{-}$by $\mathrm{AOB}$, and $\mathrm{NO}_{2}{ }^{-}$ oxidation to $\mathrm{NO}_{3}{ }^{-}$by nitrite oxidizing bacteria (NOB). Growth was described by a single substrate limited Monod function for $\mathrm{AOB}$ and by a $1^{\text {st }}$ order function for NOB, since no significant $\mathrm{NO}_{2}{ }^{-}$ accumulation $\left(<0.15 \mathrm{mg} \mathrm{NO}_{2}{ }^{-}-\mathrm{N} / \mathrm{L}\right)$ was detected during any of the experiments. Biomass loss was described by a $1^{\text {st }}$ order function with an assumed coefficient b equal to $0.05 \mathrm{~d}^{-1}$ for both AOB and NOB (Queinnec et al. 2006) to include both cell decay and detachment. External mass transfer of dissolved components was subject to a boundary layer with thickness calculated at $4.2 \times 10^{-5} \mathrm{~m}$ (Tatari et al. 2013), whereas diffusion in the biofilm was modeled considering that biofilm diffusivity equals 0.8 times the water diffusivity (Eberl et al. 2006). Diffusivity in water, calculated

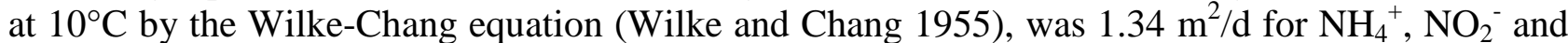
$\mathrm{NO}_{3}{ }^{-}$, and $1.27 \mathrm{~m}^{2} / \mathrm{d}$ for $\mathrm{O}_{2}$. Influent dissolved $\mathrm{O}_{2}$ and $\mathrm{NH}_{4}{ }^{+}-\mathrm{N}$ concentrations were 8 and $1 \mathrm{mg} / \mathrm{L}$ respectively. Growth yields were assumed at 0.14 and $0.08 \mathrm{~g}$ biomass-COD/g N removed for AOB and NOB, respectively (Queinnec et al. 2006).

The model for each column was calibrated by fitting the observed $\mathrm{NH}_{4}{ }^{+}$and $\mathrm{NO}_{2}^{-}$effluent concentrations during the 3 loading up-shifts simultaneously. Initial AOB density at each up-shift was the experimentally determined density before the experiments, corrected for growth until the time of the up-shift. Density increase due to growth was calculated by multiplying the AOB yield with the mass of $\mathrm{NH}_{4}^{+}$removed until the time of each up-shift. Due to the unexpectedly high density of Nitrospira compared to AOB (Section 3.2) and the uncertainty on their actual role in $\mathrm{NH}_{4}{ }^{+}$removal under the tested conditions, the initial NOB biofilm density was estimated by a 3 to 1 ratio of AOB to NOB densities based on electron stoichiometry (Hagopian and Riley 1998). Details on the calculation of biofilm densities and the parameter estimation algorithm are in the SI (Sections II and III, respectively). For each column the estimated parameters were the halfsaturation coefficient for $\mathrm{NH}_{4}{ }^{+}$removal $\mathrm{K}_{\mathrm{S}}\left(\mathrm{mg} \mathrm{NH}{ }_{4}^{+}-\mathrm{N}-/ \mathrm{L}\right)$, and the maximum specific $\mathrm{NH}_{4}{ }^{+}$ utilization rate $\mathrm{q}_{\max }\left(\mathrm{g} \mathrm{NH}_{4}{ }^{+}-\mathrm{N} / \mathrm{g} \mathrm{COD} / \mathrm{d}\right)$. For NOB, a $1^{\text {st }}$ order growth coefficient was estimated, although the values are not reported because the NOB density was not experimentally determined. The estimated kinetic parameters were used to predict performance from the three columns at reference loading. Uncertainty intervals of effluent performance predictions were based on parameters estimate variation within their standard deviation.

\subsection{Prediction of filter performance based on depth-specific $\mathrm{NH}_{4}^{+}$removal capacities}

The observed depth-specific $\mathrm{NH}_{4}{ }^{+}$removal capacities were used to predict full-scale filter performance at instantaneous loading up-shifts, generated by increasing either the influent $\mathrm{NH}_{4}{ }^{+}$ concentration or the influent flowrate. Essentially, the filter was considered to consist of 3 depth sections, top $(0-0.10 \mathrm{~m})$, middle $(0.10-0.30 \mathrm{~m})$ and bottom $(0.30-0.50 \mathrm{~m})$, wherein volumetric removal occurred at the experimentally observed $\mathrm{NH}_{4}{ }^{+}$removal capacity of the respective depth layer. Using appropriate mass-balances across these sequential sections, the $\mathrm{NH}_{4}^{+}$effluent concentration could then be computed under increasing loading applied to the top section. Details of the procedure are in section VIII of the SI.

\section{Results \& Discussion}

\subsection{Observed $\mathrm{NH}_{4}{ }^{+}$removal rates and removal capacity}

Filter materials from top, middle and bottom layers were exposed to a reference loading of $35 \mathrm{~g}$ $\mathrm{NH}_{4}{ }^{+}-\mathrm{N} / \mathrm{m}^{3} / \mathrm{d}$ for 9 days in a lab-scale column assay, with influent concentration constant at $1 \mathrm{mg}$ $\mathrm{NH}_{4}{ }^{+}-\mathrm{N} / \mathrm{L}$. The top layer column displayed complete removal from day 1 , and throughout the entire experiment (Figure 1A). Effluent $\mathrm{NH}_{4}{ }^{+}-\mathrm{N}$ from the middle layer column was $0.70 \mathrm{mg} / \mathrm{L} 1$ day after 

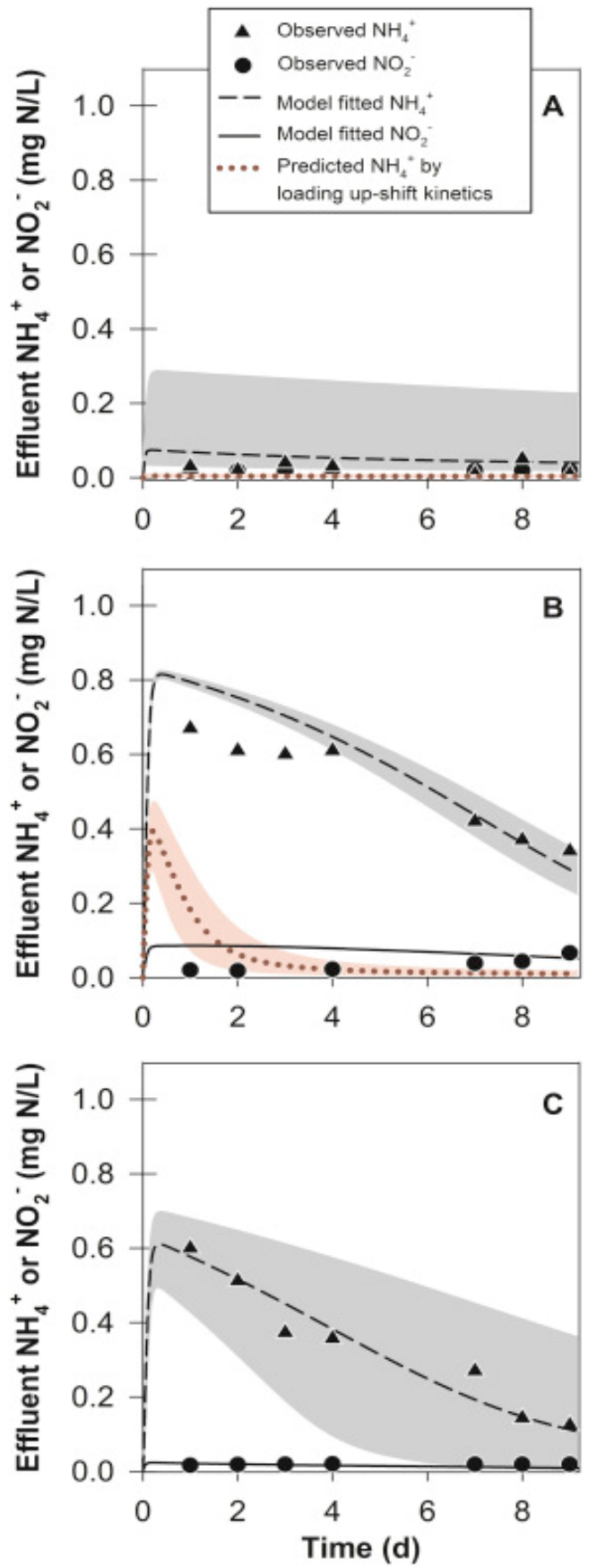

Figure 1. Observed and model fitted effluent $\mathrm{NH}_{4}{ }^{+}$and $\mathrm{NO}_{2}^{-}$ concentrations from the top (A), middle (B) and bottom (C) layer columns at reference loading $\left(35 \mathrm{~g} / \mathrm{NH}_{4}{ }^{+}-\mathrm{N} / \mathrm{m}^{3}\right.$ filter material/d). The green line and green shaded areas in panels $\mathrm{A}$ and $\mathrm{B}$ illustrate the $\mathrm{NH}_{4}{ }^{+}$effluent concentration and its uncertainty interval predicted by applying the kinetic parameters estimated at loading up-shifts. The black lines and grey shaded areas illustrate the concentrations fitted at reference loading and their uncertainty interval, after estimation of new maximum specific $\mathrm{NH}_{4}^{+}$utilization rates. Uncertainty intervals were calculated from the parameters estimate variation within their standard deviation. start-up, and decreased gradually to 0.34 $\mathrm{mg} / \mathrm{L}$ on day 9 (Figure 1B). The bottom layer column showed a similar trend with the effluent $\mathrm{NH}_{4}{ }^{+}-\mathrm{N}$, decreasing from 0.60 to $0.12 \mathrm{mg} / \mathrm{L}$ over the 9 days (Figure 1C). $\mathrm{NO}_{2}{ }^{-}-\mathrm{N}$ effluent concentrations were below $0.15 \mathrm{mg} \mathrm{NO}_{2}^{-}-\mathrm{N} / \mathrm{L}$ for all columns. The low effluent $\mathrm{NO}_{2}^{-}-\mathrm{N}$ concentrations indicate an excess of $\mathrm{NO}_{2}^{-}$vs $\mathrm{NH}_{4}^{+}$ removal activity. The highest $\mathrm{NO}_{2}{ }^{-}$ concentration was observed on days 7-9 in the middle layer column (Figure 1B), possibly caused by the rapid increase in the $\mathrm{NH}_{4}^{+}$removal activity. Different performances of the three layers on day 1 indicate stratification of $\mathrm{NH}_{4}^{+}$removal in the filter, with the highest removal rate at the top, consistent with the pilot-scale observations by Lee et al. (2014).

During the experiment, the loading was transiently up-shifted for 3-5 h to observe the effluent $\mathrm{NH}_{4}{ }^{+}$and $\mathrm{NO}_{2}{ }^{-}$concentration responses from the three columns. Influent concentration was maintained at $1 \mathrm{mg}$ $\mathrm{NH}_{4}{ }^{+}-\mathrm{N} / \mathrm{L}$. Loading up-shift to $88 \mathrm{~g} \mathrm{NH}_{4}{ }^{+}-$ $\mathrm{N} / \mathrm{m}^{3}$ filter material/d did not affect the $\mathrm{NH}_{4}{ }^{+}-\mathrm{N}$ effluent concentration in the top layer column (Figure 2A). At up-shifts to 175 and $350 \mathrm{~g} \mathrm{NH}_{4}{ }^{+}-\mathrm{N} / \mathrm{m}^{3}$ filter material/d, the effluent $\mathrm{NH}_{4}{ }^{+}-\mathrm{N}$ concentration increased and stabilized to new pseudo steady-state values of 0.09 $( \pm 0.02)$ and $0.34 \quad( \pm 0.02) \quad \mathrm{mg} / \mathrm{L}$, respectively. For the middle layer column, the effluent $\mathrm{NH}_{4}{ }^{+}-\mathrm{N}$ concentration increased from $0.60( \pm 0.01) \mathrm{mg} / \mathrm{L}$ at reference loading to $0.73 \mathrm{mg} / \mathrm{L}( \pm 0.03)$ at the lowest loading up-shift and to 0.86 $( \pm 0.05) \mathrm{mg} / \mathrm{L}$ at the highest loading upshift (Figure 2B). Similarly, for the bottom layer column, the effluent increased from $0.37( \pm 0.09)$ at reference loading to $0.68( \pm 0.02) \mathrm{mg} / \mathrm{L}$ at the lowest loading up-shift and to $0.93( \pm 0.10) \mathrm{mg} / \mathrm{L}$ at the highest loading up-shift (Figure 2C). Overall, the top layer column maintained 

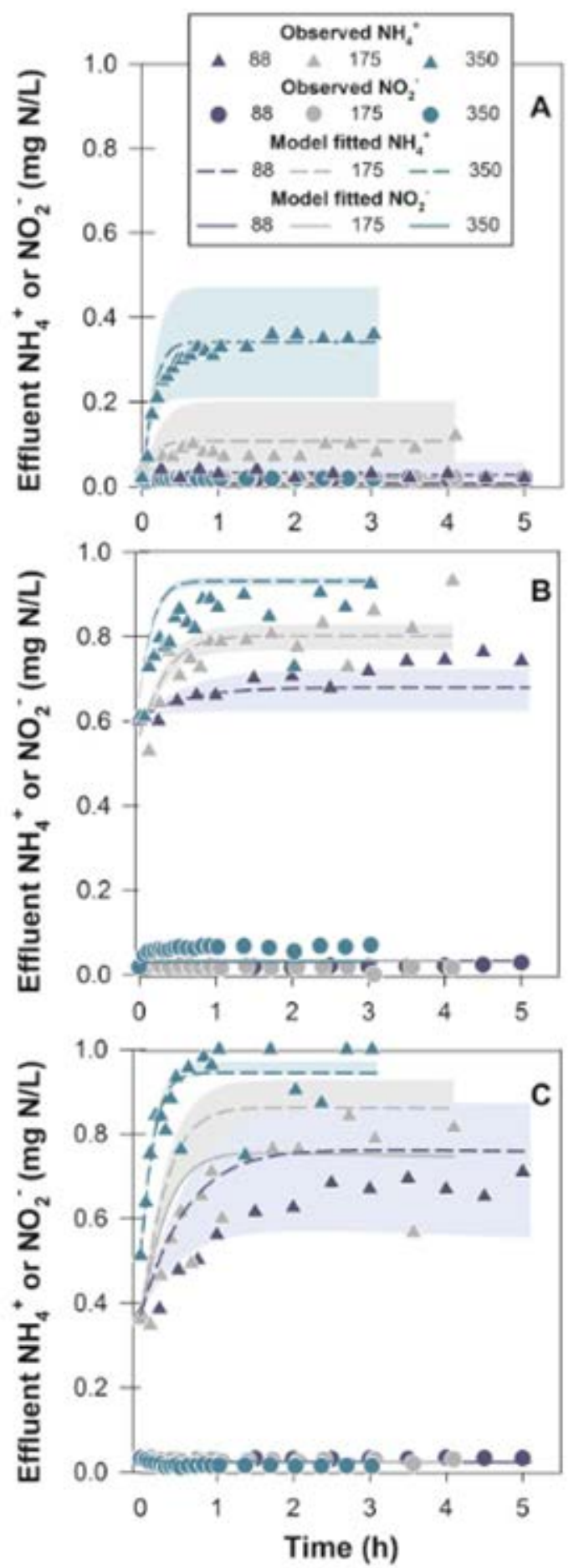

Figure 2. Observed and model fitted effluent $\mathrm{NH}_{4}^{+}$and $\mathrm{NO}_{2}{ }^{-}$concentrations from the top (A), middle (B) and bottom (C) layer columns during the short-term loading up-shifts to 88,175 and $350 \mathrm{~g} / \mathrm{NH}_{4}{ }^{+}-\mathrm{N} / \mathrm{m}^{3}$ filter material/d. Shaded areas illustrate the uncertainty interval of the fitted $\mathrm{NH}_{4}{ }^{+}$effluent concentrations at each up-shift, calculated from the parameters estimate variation within their standard deviation. the lowest $\mathrm{NH}_{4}^{+}$effluent concentrations at all investigated loadings.

Based on these pseudo steady-state $\mathrm{NH}_{4}^{+}$ concentrations, the removal rate for each depth layer was calculated at all loading conditions (Table 1). The maximum observed $\mathrm{NH}_{4}{ }^{+}$removal rate from the bottom layer column was $28 \mathrm{~g}$ $\mathrm{NH}_{4}{ }^{+}-\mathrm{N} / \mathrm{m}^{3}$ filter material/d, from the middle layer column $42 \mathrm{~g} \mathrm{NH}_{4}{ }^{+}-\mathrm{N} / \mathrm{m}^{3}$ filter material/d, and from the top layer column $223 \mathrm{~g} \mathrm{NH}_{4}{ }^{+}-\mathrm{N} / \mathrm{m}^{3}$ filter material/d (Table 1). These maximum observed removal rates are essentially the $\mathrm{NH}_{4}{ }^{+}$ removal capacities at the respective depths, except for the top layer where a true maximum was not yet reached within the investigated loading range.

Overall, these observations demonstrate strong stratification of $\mathrm{NH}_{4}^{+}$removal and capacity. These $\mathrm{NH}_{4}^{+}$removal capacities are consistent with the ones estimated by Lee et al. (2014) in their pilot-scale study at the same waterworks that ranged from roughly $250 \mathrm{~g} \mathrm{NH}_{4}{ }^{+}-\mathrm{N} / \mathrm{m}^{3}$ filter material/d at the top to $35 \mathrm{~g} \mathrm{NH}_{4}^{+}-\mathrm{N} / \mathrm{m}^{3}$ filter material/d at the bottom of the filter. Capacity estimation using the lab-scale column assay is much quicker, needing only 3 days instead of the long start-up and stabilization times required for pilot-scale investigations. Moreover, the main advantage of this method is that the loading applied at the deeper layers can be controlled, while in pilot-scale filters loadings are dictated by the removal from the top layer.

\subsection{Active $\mathrm{NH}_{4}{ }^{+}$oxidizers}

During reference loading conditions, the effluent $\mathrm{NH}_{4}{ }^{+}$concentration from the middle and bottom filter layers decreased with time, suggesting growth of active $\mathrm{NH}_{4}{ }^{+}$oxidizers. Nitrosomonas and Nitrosospira (hereafter referred to together as AOB) are typically considered as the active $\mathrm{NH}_{4}{ }^{+}$ oxidizers, although AOA have also been identified in drinking water filters (Bai et al. 2013, de Vet et al. 2011, Kasuga et al. 2010, Niu et al. 2013) and are present at the investigated waterworks (Gülay et al. 2014, Lee et al. 2014). Moreover, some Nitrospira have recently been described to have the potential of oxidizing both 
$\mathrm{NH}_{4}{ }^{+}$and $\mathrm{NO}_{2}{ }^{-}$, carrying out the complete $\mathrm{NH}_{4}{ }^{+}$oxidation pathway (Daims et al. 2015, Palomo et al. 2016, van Kessel et al. 2015). To observe if growth of any of the above microbial types was related with the activity increase in the middle and bottom layer columns, we examined their densities before and after the column experiments.

Only for AOB there was a substantial increase in density observed for the middle and bottom layer columns, at ca. 700 and $200 \%$ respectively (Figure 3). In the top layer column, AOB density increased by 30\% during the 9 days of experimental time (Figure 3). Densities of other microbial types did not consistently increase in the middle and bottom layer columns. AOB growth is therefore associated with the observed activity increase, and AOB were likely the main $\mathrm{NH}_{4}{ }^{+}$ oxidizers during the experiments. Additionally, initial AOB densities varied consistently with the observed activity variation, with the highest density measured at the top $\left(31 \pm 12 \times 10^{12}\right.$ cells $/ \mathrm{m}^{3}$ filter material) and lower densities measured at the middle $\left(2.3 \pm 0.4 \times 10^{12}\right.$ cells $/ \mathrm{m}^{3}$ filter material $)$ and the bottom $\left(6.2 \pm 3.7 \times 10^{12}\right.$ cells $/ \mathrm{m}^{3}$ filter material) layers (Figure 3$)$.

The presence of AOA at densities as high as $8.5-16 \times 10^{10}$ cells $/ \mathrm{m}^{3}$ is puzzling, since these densities are comparable with densities quantified by amoA targeted qPCR, which ranged from $1-70 \times 10^{10}$ cells $/ \mathrm{m}^{3}$ filter material. To examine the possible involvement of AOA to nitrification in the experiments, we calculated their hypothetical cell specific $\mathrm{NH}_{4}{ }^{+}$removal rates at reference loading, based on the observed removal rates (Figure S5 in SI). The removal rates are approximately 4 orders of magnitude higher than previous reports (Kim et al. 2012, Prosser and Nicol 2012, Santoro and Casciotti 2011), suggesting that AOA are not responsible for nitrification under the imposed experimental conditions. Nevertheless, AOA presence at densities comparable with the AOB suggests in situ physiological activity in the filter. The loading conditions applied during the column experiments were compared with the in situ filter loading conditions, based on the $\mathrm{NH}_{4}{ }^{+}$ depth profile in the filter. As also observed by Lee et al. (2014) and Tatari et al. (2013), the $\mathrm{NH}_{4}{ }^{+}$ concentration decreased steeply with depth, dropping below $0.03 \mathrm{mg} / \mathrm{L} \mathrm{NH}_{4}{ }^{+}-\mathrm{N}$ at $0.15 \mathrm{~m}$ depth during all 6 sampling campaigns (Figure S6 in SI). The in situ loadings at the top, middle and bottom filter layers, calculated from the observed $\mathrm{NH}_{4}{ }^{+}$concentration (average from all sampling campaigns at that depth) and the flowrate, were 138, 3.5, and $0.3 \mathrm{~g} \mathrm{NH}_{4}{ }^{+}-\mathrm{N} / \mathrm{m}^{3} / \mathrm{d}$ at the top, middle, and bottom layers, respectively. The reference loading (35 $\mathrm{NH}_{4}{ }^{+}-\mathrm{N} / \mathrm{m}^{3}$ filter material/d) in the column assays was therefore lower than the average full-scale loading at the top layer, but much higher than the average in situ loadings in the middle and bottom layers.

Densities of $\mathrm{AOB}$ and AOA with depth were quantified at higher resolution and were related to the in situ $\mathrm{NH}_{4}{ }^{+}$loadings at each depth (Figure 4). Densities illustrated in Figure 4 are based on amoA qPCR quantification, and thus AOB densities are lower than the 16S-rRNA based densities reported in Figure 3. AOA densities marginally increased with depth and decreasing loading, whereas AOB densities decreased up to 2 orders of magnitude with depth (Figure 4). AOA exceeded AOB at low loadings, and AOB exceeded AOA at high loadings (Figure 4). These observations agree with previous findings that AOA activity is relevant at low $\mathrm{NH}_{4}{ }^{+}$concentrations due to their high affinity (Martens-Habbena et al. 2009, Martens-Habbena and Stahl 2011, Niu et al. 2013).

Ultimately, our results suggest that under the imposed experimental conditions, AOB govern $\mathrm{NH}_{4}{ }^{+}$ oxidation due to high $\mathrm{NH}_{4}^{+}$loadings. AOA are present and outnumber $\mathrm{AOB}$ in the middle and bottom filter layers, suggesting a key role of AOA for in situ $\mathrm{NH}_{4}{ }^{+}$removal due to the low $\mathrm{NH}_{4}{ }^{+}$ loadings at these filter depths.

\subsection{AOB cell specific $\mathrm{NH}_{4}^{+}$removal rates}

Cell specific $\mathrm{NH}_{4}{ }^{+}$removal rates were calculated at each loading by normalizing the observed $\mathrm{NH}_{4}{ }^{+}$ removal rates for the volumetric AOB densities, which were experimentally determined (day 1) or 
calculated (for the up-shifts). The cell specific $\mathrm{NH}_{4}{ }^{+}$removal rates are within the high end of previously reported estimates that range from 0.30 to $11 \times 10^{3} \mathrm{fg} \mathrm{NH}_{4}{ }^{+}-\mathrm{N} / \mathrm{cell} / \mathrm{d}$ (de Vet et al. 2011, Lee et al. 2014, Prosser 1989) (Figure 5). At reference loading, the cell specific $\mathrm{NH}_{4}{ }^{+}$removal rate in the top layer column was lower than the other columns due to the higher AOB density in this layer. With loading increase, the cell specific $\mathrm{NH}_{4}{ }^{+}$removal rates increased 6.5 and 2.8 times in the top and middle layer column, but no increase was observed in the bottom layer column (Table 1), indicating that cells in the bottom layer had already reached their maximum $\mathrm{NH}_{4}{ }^{+}$removal rate of $3.4 \times 10^{3}( \pm 0.95) \mathrm{fg} \mathrm{NH}_{4}{ }^{+}-\mathrm{N} /$ cell/d (average from all loadings).

Table 1. Overview of $\mathrm{NH}_{4}^{+}$removal rates (volumetric and cell specific) at reference loading and loading up-shifts for the three investigated depth layers.

\begin{tabular}{|c|c|c|c|}
\hline & Top & Middle & Bottom \\
\hline \multicolumn{4}{|l|}{ Observed removal rates $\left(\mathrm{g} \mathrm{NH}_{4}^{+}-\mathrm{N} / \mathrm{m}^{3}\right.$ filter material/d) } \\
\hline Reference loading (35 $\mathrm{g} \mathrm{NH}_{4}{ }^{+}-\mathrm{N} / \mathrm{m}^{3}$ filter material/d) & $34\left( \pm 0.87^{\dagger}\right)$ & $12( \pm 2.2)$ & $21( \pm 3.8)$ \\
\hline Up-shift to $88 \mathrm{~g} \mathrm{NH}_{4}{ }^{+}-\mathrm{N} / \mathrm{m}^{3}$ filter material/d & $88( \pm 0.54)$ & $11( \pm 2.6)$ & $24( \pm 1.8)$ \\
\hline Up-shift to $175 \mathrm{~g} \mathrm{NH}_{4}^{+}-\mathrm{N} / \mathrm{m}^{3}$ filter material/d & $167( \pm 3.2)$ & $29( \pm 11)$ & $46( \pm 22)$ \\
\hline Up-shift to $350 \mathrm{~g} \mathrm{NH}_{4}{ }^{+}-\mathrm{N} / \mathrm{m}^{3}$ filter material/d & $223( \pm 6.6)$ & $42( \pm 19)$ & $20( \pm 35)$ \\
\hline $\begin{array}{l}\text { Ratio of removal rate at } 350 \text { to removal rate at } 35 \\
\mathrm{~g} \mathrm{NH}_{4}^{+}-\mathrm{N} / \mathrm{m}^{3} \text { filter material/d loadings }\end{array}$ & 6.6 & 3.6 & 1 \\
\hline $\begin{array}{l}\mathrm{NH}_{4}^{+} \text {removal capacity } \\
\left(\mathrm{g} \mathrm{NH}_{4}^{+}-\mathrm{N} / \mathrm{m}^{3} \text { filter material/d) }\right.\end{array}$ & $>223$ & 42.0 & $27.5^{\ddagger}$ \\
\hline $\begin{array}{l}\text { Highest observed cell specific } \mathrm{NH}_{4}{ }^{+} \text {removal rate for } \\
\text { AOB }\left(\times 10^{3} \text { fg } \mathrm{NH}_{4}^{+}-\mathrm{N} / \text { cell/d }\right)\end{array}$ & 7.1 & 14.2 & 2.6 \\
\hline $\begin{array}{l}\text { Ratio of AOB cell specific removal rate at } 350 \text { to removal } \\
\text { at } 35 \mathrm{~g} \mathrm{NH}_{4}^{+}-\mathrm{N} / \mathrm{m}^{3} \text { filter material/d loadings }\end{array}$ & 6.5 & 2.8 & 1 \\
\hline
\end{tabular}
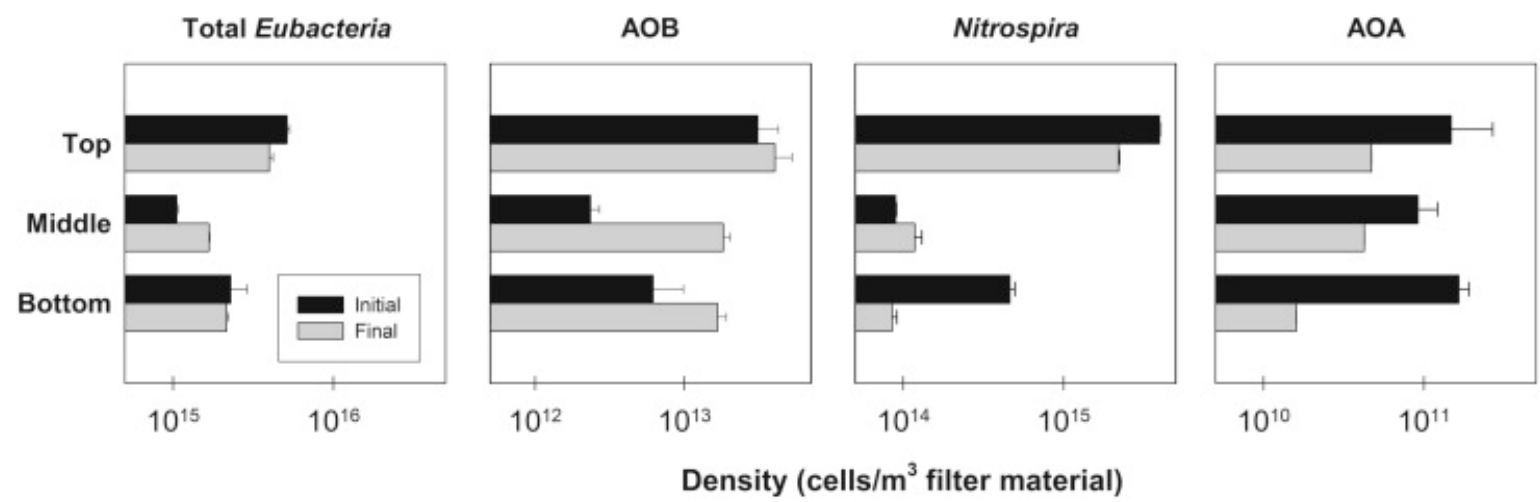

Figure 3. Microbial densities measured by qPRC (16S-rRNA based for Total Eubacteria, AOB and Nitrospira, amoA based for AOA) before and after the 9 days of column experiments. Error bars represent the standard deviation of triplicate DNA extractions and qPCR measurements. 
This maximum cell specific $\mathrm{NH}_{4}{ }^{+}$removal rate was lower than the rates observed in the top and middle layer columns. Additionally, the maximum cell specific $\mathrm{NH}_{4}{ }^{+}$removal rate in the top layer column was not reached within the investigated loading range, and is higher than the values reported in Figure 5. Ultimately, the three layers exhibited different maximum cell specific $\mathrm{NH}_{4}{ }^{+}$ removal rates, suggesting that $\mathrm{AOB}$ with different physiological behaviors were active at the different layers.

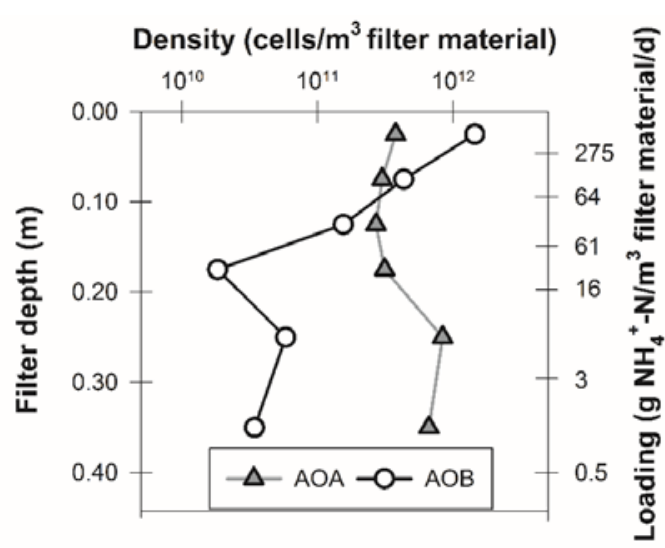

Figure 4. Distribution of $\mathrm{AOB}$ and AOA densities (amoA based qPCR) and in situ filter loading with depth in the full-scale filter.

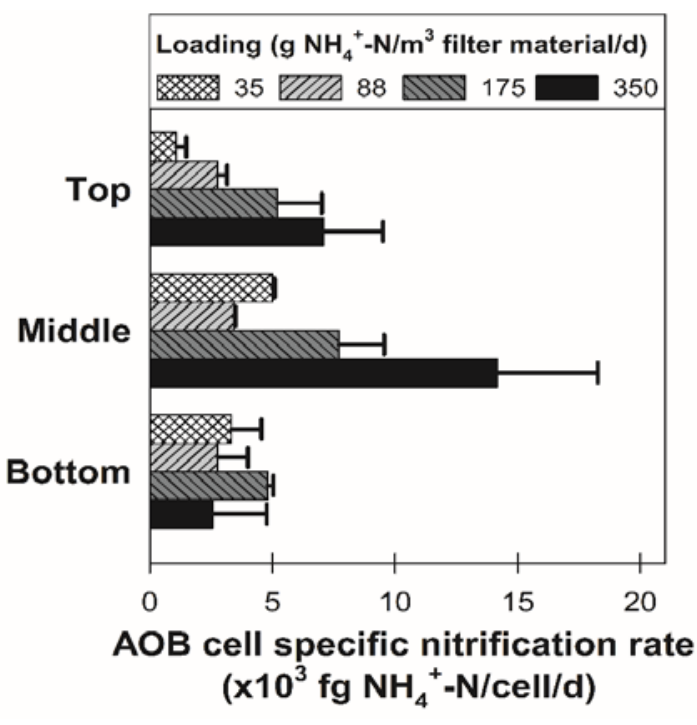

Figure 5. Cell specific $\mathrm{NH}_{4}^{+}$removal rates, calculated by normalizing the observed $\mathrm{NH}_{4}{ }^{+}$removal rates for the AOB density at the time that each loading was applied in the columns. Error bars illustrate the error calculated by propagation of the standard deviations of the removal rate and the $\mathrm{AOB}$ density.

\subsection{Model-based kinetic interpretation}

$\mathrm{NH}_{4}{ }^{+}$removal during the loading up-shifts was described by a 1-D biofilm model to estimate the best fit kinetic parameters $\mathrm{K}_{\mathrm{S}}$ and $\mathrm{q}_{\max }$ for each column. Estimated $\mathrm{K}_{\mathrm{S}}$ values for $\mathrm{NH}_{4}{ }^{+}$ranged from 0.22 for the top to $0.13 \mathrm{mg} \mathrm{NH}_{4}{ }^{+}-\mathrm{N} / \mathrm{L}$ for the bottom layer column (Table 2). The estimated Ks values compared with the measured effluent $\mathrm{NH}_{4}{ }^{+}$concentrations indicate a shift of removal kinetics from first order in the top to zero order in the bottom layer column. Identifiability of $\mathrm{K}_{\mathrm{S}}$ was poor for the middle layer column; $\mathrm{K}_{\mathrm{S}}$ was therefore set to $0.22 \mathrm{mg} \mathrm{NH}_{4}{ }^{+}-\mathrm{N} / \mathrm{L}$, as for the top layer, to allow $\mathrm{q}_{\max }$ estimation. The chosen $\mathrm{K}_{\mathrm{S}}$ value was justified by the zero order behavior observed from the middle layer, and only slight differences in the residual errors and the estimated values of the other parameters were observed by setting the $\mathrm{K}_{\mathrm{S}}$ value to $0.13 \mathrm{mg} \mathrm{NH}_{4}{ }^{+}-\mathrm{N} / \mathrm{L}$, as estimated in the bottom layer (data not shown). Estimated $\mathrm{q}_{\max }$ values for the loading upshifts ranged from $0.32 \mathrm{~g} \mathrm{NH}_{4}{ }^{+}-\mathrm{N} / \mathrm{g} \mathrm{COD} / \mathrm{d}$ for the middle to $0.07 \mathrm{~g} \mathrm{NH}_{4}{ }^{+}-\mathrm{N} / \mathrm{g} \mathrm{COD} / \mathrm{d}$ for the bottom layer column. Residual errors for the targeted variables (effluent $\mathrm{NH}_{4}{ }^{+}$and $\mathrm{NO}_{2}{ }^{-}$concentrations) are reported in the SI (Table S2). Estimation of different $\mathrm{q}_{\max }$ for the three layers is consistent with the activity observations and confirms the variation of the intrinsic $\mathrm{NH}_{4}{ }^{+}$removal capacity with depth.

Reference loading performances for the top and middle layer columns were overestimated by applying the parameters estimated at loading up-shifts: predicted $\mathrm{NH}_{4}{ }^{+}$effluent concentrations from the top layer column were roughly $0.004( \pm 0.0004) \mathrm{mg} \mathrm{NH}_{4}{ }^{+}-\mathrm{N} / \mathrm{L}$, whereas the observed concentration ranged from 0.01 to $0.03 \mathrm{mg} \mathrm{NH}_{4}{ }^{+}-\mathrm{N} / \mathrm{L}$ (Figure 1A). Similarly, the observed $\mathrm{NH}_{4}{ }^{+}$ 
effluent concentrations exceeded the model predicted concentrations from the middle layer column, falling outside the model uncertainty interval (Figure 1B). Hence, new $\mathrm{q}_{\max }$ values were estimated by fitting the $\mathrm{NH}_{4}{ }^{+}$and $\mathrm{NO}_{2}{ }^{-}$profiles at reference loading and the final AOB density at the end of the experiments, with $\mathrm{K}_{\mathrm{S}}$ values and all other parameters kept constant during model re-calibration. Newly estimated $\mathrm{q}_{\max }$ values at reference loading were lower for both columns, decreasing by factor 4.8 for the top and 3.6 for the middle layer columns (Table 2). This performance overestimation was not observed in the bottom layer column, where kinetic parameters estimated at the loading upshifts adequately described the effluent $\mathrm{NH}_{4}{ }^{+}$concentration at reference loading (Figure 1C). Increase of the $q_{\max }$ value with loading suggests that active nitrifiers in the top and middle layers have the capacity to immediately up-shift their removal rates according to the substrate loadings. To the authors' knowledge, such up-shift capacity has not previously been reported; neither was it observed in the bottom layer column where active nitrifiers had already reached their capacity at the lowest loading up-shift.

Table 2. Model estimated kinetic parameters for the three columns at reference loading. Values are reported with the standard error of the parameter estimates.

\begin{tabular}{|c|c|c|c|c|}
\hline & $\begin{array}{c}\mathrm{NH}_{4}^{+} \text {half } \\
\text { saturation } \\
\text { concentration, } \mathrm{K}_{\mathrm{S}} \\
\left(\mathrm{mg} \mathrm{NH}_{4}^{+}-\mathrm{N} / \mathrm{L}\right)\end{array}$ & $\begin{array}{c}\text { Maximum specific } \mathrm{NH}_{4}^{+} \\
\text {utilization rate at loading } \\
\text { up-shifts, } q_{\max } \\
\left.\text { (g COD/g NH}{ }_{4}^{+}-\mathrm{N} / \mathrm{d}\right)\end{array}$ & $\begin{array}{c}\text { Maximum specific } \mathrm{NH}_{4}^{+} \\
\text {utilization rate at reference } \\
\text { loading, } \mathrm{q}_{\max } \\
\left(\mathrm{g} \mathrm{COD} / \mathrm{g} \mathrm{NH}_{4}^{+}-\mathrm{N} / \mathrm{d}\right)\end{array}$ & $\begin{array}{c}q_{\max } \\
\text { up-shift } \\
\text { factor }^{\ddagger}\end{array}$ \\
\hline Top & $0.22 \pm 0.09$ & $0.29 \pm 0.05$ & $0.06 \pm 0.03$ & 4.8 \\
\hline Middle & $0.22^{\dagger}$ & $0.32 \pm 0.02$ & $0.09 \pm 0.01$ & 3.6 \\
\hline Bottom & $0.13 \pm 0.09$ & $0.07 \pm 0.01$ & $0.07 \pm 0.01$ & 1 \\
\hline
\end{tabular}

${ }^{\dagger}$ Numerical estimation did not converge to a unique $\mathrm{K}_{\mathrm{S}}$ value; the top layer column $\mathrm{Ks}$ value was used to estimate the remaining parameters.

${ }^{\ddagger}$ Calculated as $q_{\max }$ at loading up-shifts $/ q_{\max }$ at refrence loading

\subsection{Predicting full-scale filter capacity based on the depth-specific $\mathrm{NH}_{4}{ }^{+}$ removal capacity measurements}

Using the depth specific $\mathrm{NH}_{4}{ }^{+}$removal capacity, we predicted the overall filter response to transient loading changes. All filter layers displayed an $\mathrm{NH}_{4}{ }^{+}$removal capacity that exceeded the in situ loading, although this additional capacity was clearly stratified and concentrated at the top. This stratification was a result of both AOB density and biokinetic behavior differences, with the top and middle layers exhibiting an up-shift capacity at high loadings not exhibited from the bottom layer.

Based on the estimated $\mathrm{NH}_{4}{ }^{+}$removal capacities, we predicted the overall filter response to instantaneous loading increases. Ultimately, our goal was to assess to what degree the filter loading can be increased without compromising the filter effluent quality. The loading was increased either by increasing the influent $\mathrm{NH}_{4}{ }^{+}$concentration or the influent flowrate, and the required filter depth to maintain strict effluent guideline limits $\left(0.05 \mathrm{mg} \mathrm{NH}_{4}{ }^{+} / \mathrm{L}\right)$ was computed for both scenarios.

The model predicted filter response to loading increases was different for the two scenarios (Figure 6). At increasing influent concentration, we predict that the filter (assumed $0.5 \mathrm{~m}$ depth) can maintain effluent limits up to a $91 \mathrm{~g} \mathrm{NH}_{4}{ }^{+} / \mathrm{m}^{3}$ filter material/d loading (Figure 6), corresponding to an increase from 0.13 to $0.38 \mathrm{mg} \mathrm{NH}_{4}{ }^{+}-\mathrm{N} / \mathrm{L}$ in the influent concentration. Higher permissible 
loading increases are predicted for the increased flowrate scenario, up to $116 \mathrm{~g} \mathrm{NH}_{4}^{+} / \mathrm{m}^{3}$ filter material/d (Figure 6) corresponding to a flowrate increase from 1.73 to $6.4 \times 10^{6} \mathrm{~L} / \mathrm{d}$. Predicted effluent concentrations for both scenarios are illustrated in SI (Figure S7). Filter responses are clearly more robust to flowrate increase than to influent concentration increase at equivalent volumetric loadings. Yet, removal from each filter section is only dependent on loading; differences in the depth needed to remove equivalent loadings are the result of higher degrees of dilution at higher flowrates (eq.S9-S11 in SI). Overall the predicted $\mathrm{NH}_{4}{ }^{+}$removal capacity is significantly higher (ca. 28\%) than the safe operating loading window predicted by Lee et al. 2014, who estimated a maximum allowable loading of $75 \mathrm{~g} \mathrm{NH}_{4}{ }^{+} / \mathrm{m}^{3}$ filter material/d for the scenario of increased influent concentration. This difference may reflect a slightly different evolution of the $\mathrm{NH}_{4}{ }^{+}$removal during the pilot-scale filter start-up and stabilization, possibly due to different flow distributions and backwashing hydraulics in the two systems.
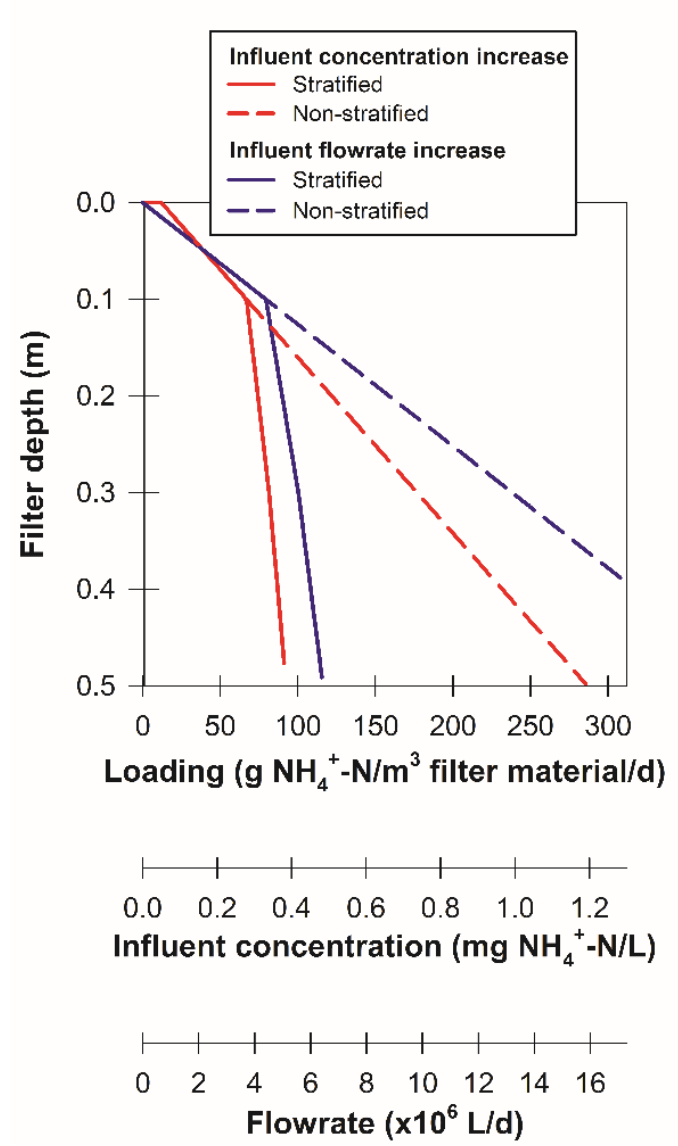

Figure 6. Model predicted depth needed in the fullscale filter to remove instantaneous loading up-shifts and retaining compliance with strict effluent guideline limits $\left(0.05 \mathrm{mg} / \mathrm{L} \mathrm{NH}_{4}^{+}\right)$. Loading was increased by increasing the influent concentration (from 0 to $1.3 \mathrm{mg} \mathrm{NH}_{4}{ }^{+}-\mathrm{N} / \mathrm{L}$ keeping the flowrate constant at $1.73 \times 10^{6} \mathrm{~L} / \mathrm{d}$ ), or increasing the flowrate (from 0 to $17.3 \times 10^{6} \mathrm{~L} / \mathrm{d}$ keeping the influent concentration constant at $0.13 \mathrm{mg} \mathrm{NH}_{4}{ }^{+} \mathrm{-N} / \mathrm{L}$ ).
Filter performance in both scenarios is overestimated if the filter is assumed non-stratified and biokinetics observed for the top layer are considered (Figure 6). The different filter layers behave differently because they are exposed to different in situ loadings and have different $\mathrm{NH}_{4}{ }^{+}$ removal capacities. The deeper filter layers have higher $\mathrm{NH}_{4}^{+}$removal capacities than the ones exhibited at the in situ loadings, and these additional capacities can be accessed when $\mathrm{NH}_{4}{ }^{+}$ penetrates deeper in the filter. $\mathrm{NH}_{4}{ }^{+}$removal capacity of these deeper layers remains however lower than for the top layers. Therefore, it is essential to examine and account for possible stratification in a filter, to avoid low filter efficiency or $\mathrm{NH}_{4}{ }^{+}$breakthrough in the effluent, when loading up-shifts are considered.

\subsection{Conclusions}

This study investigated the $\mathrm{NH}_{4}{ }^{+}$removal capacity at different depths of a full-scale rapid sand filter. Filter material collected from selected depths was investigated in a lab-scale continuous-flow assay under conditions that maintained the antecedent hydrodynamic properties in order to reflect behavior of the full-scale filter.

The main findings were:

Strong stratification of $\mathrm{NH}_{4}{ }^{+}$removal rates and $\mathrm{NH}_{4}^{+}$removal capacity were consistent with the decrease of AOB density with depth.

- $\quad$ AOB density increased consistently with the increase of $\mathrm{NH}_{4}^{+}$removal rate over time, suggesting the primary involvement of AOB to nitrification under the experimental conditions. No increase in the density of total Eubacteria, 
Nitrospira or AOA was observed.

- The maximum AOB cell specific $\mathrm{NH}_{4}{ }^{+}$removal rate in the bottom layer was lower than in the top and middle layers, suggesting that nitrifiers with different metabolic physiologies or different microbial types were active at the different depths.

- The $\mathrm{NH}_{4}{ }^{+}$removal biokinetic behavior was stratified in the filter and different up-shift capacities were observed with depth. In the top and middle layers, an instantaneous activity up-shift was observed with loading increase, while this was absent for the bottom layer.

- The predicted maximum filter capacity that would retain compliance with the effluent $\mathrm{NH}_{4}{ }^{+}$ guideline limits was approximately 4 times higher than the reference operating $\mathrm{NH}_{4}{ }^{+}$ loading.

\section{Acknowledgements}

This work was supported by the Danish Council for Strategic Research via the project DWBiofilters. The authors acknowledge the Urban Water Technology Research School and the waterworks involved in this study.

\section{References}

Albers, C.N., Ellegaard-Jensen, L., Harder, C.B., Rosendahl, S., Knudsen, B.E., Ekelund, F. and Aamand, J. (2015) Groundwater chemistry determines the prokaryotic community structure of waterworks sand filters. Environmental Science \& Technology 49(2), 839-846.

Bai, Y., Liu, R., Liang, J. and Qu, J. (2013) Integrated metagenomic and physiochemical analyses to evaluate the potential role of microbes in the sand filter of a drinking water treatment system. Plos One 8(4).

Chu, C.W., Lu, C.Y. and Lee, C.M. (2005) Effects of inorganic nutrients on the regrowth of heterotrophic bacteria in drinking water distribution systems. Journal of Environmental Management 74(3), 255-263.

Council Directive 98/93/EC (1998) Quality of Water Intended for Human Consumption, Annex I, Part C.

Daims, H., Lebedeva, E.V., Pjevac, P., Han, P., Herbold, C., Albertsen, M., Jehmlich, N., Palatinszky, M., Vierheilig, J., Bulaev, A., Kirkegaard, R.H., von Bergen, M., Rattei, T., Bendinger, B., Nielsen, P.H. and Wagner, M. (2015) Complete nitrification by Nitrospira bacteria. Nature 528(7583), 504-+.

Danish Ministry of Environment ( 2014) Regulations on water quality and control of the water supply system 292 from 26/03/2014 (In Danish).

de Vet, W., Dinkla, I.J.T., Muyzer, G., Rietveld, L.C. and van Loosdrecht, M.C.M. (2009) Molecular characterization of microbial populations in groundwater sources and sand filters for drinking water production. Water Research 43(1), 182-194.

de Vet, W., Kleerebezem, R., van der Wielen, P., Rietveld, L.C. and van Loosdrecht, M.C.M. (2011) Assessment of nitrification in groundwater filters for drinking water production by qPCR and activity measurement. Water Research 45(13), 4008-4018. 
Eberl, H., Morgenroth, E., Noguera, D., Picioreanu, C., Rittmann, B., Van Loodsdrecht, M. and Wanner, O. (2006) Mathematical modeling of biofilms, pp. 11-41, IWA publishing, London

Feng, S., Chen, C., Wang, Q.F., Zhang, X.J., Yang, Z.Y. and Xie, S.G. (2013) Characterization of microbial communities in a granular activated carbon-sand dual media filter for drinking water treatment. International Journal of Environmental Science and Technology 10(5), 917-922.

Ferris, M.J., Muyzer, G. and Ward, D.M. (1996) Denaturing gradient gel electrophoresis profiles of 16S rRNA-defined populations inhabiting a hot spring microbial mat community. Applied and Environmental Microbiology 62(2), 340-346.

Francis, C.A., Roberts, K.J., Beman, J.M., Santoro, A.E. and Oakley, B.B. (2005) Ubiquity and diversity of ammonia-oxidizing archaea in water columns and sediments of the ocean. Proceedings of the National Academy of Sciences of the United States of America 102(41), 14683-14688.

Graham, D.W., Knapp, C.W., Van Vleck, E.S., Bloor, K., Lane, T.B. and Graham, C.E. (2007) Experimental demonstration of chaotic instability in biological nitrification. Isme Journal 1(5), 385-393.

Gülay, A., Tatari, K., Musovic, S., Mateiu, R.V., Albrechtsen, H.-J. and Smets, B.F. (2014) Internal porosity of mineral coating supports microbial activity in rapid sand filters for groundwater treatment. Applied and Environmental Microbiology 80(22), 7010-7020.

Hagopian, D.S. and Riley, J.G. (1998) A closer look at the bacteriology of nitrification. Aquacultural Engineering 18(4), 223-244.

Hermansson, A. and Lindgren, P.E. (2001) Quantification of ammonia-oxidizing bacteria in arable soil by real-time PCR. Applied and Environmental Microbiology 67(2), 972-976.

Kasuga, I., Nakagaki, H., Kurisu, F. and Furumai, H. (2010) Predominance of ammonia-oxidizing archaea on granular activated carbon used in a full-scale advanced drinking water treatment plant. Water Research 44(17), 5039-5049.

Kihn, A., Laurent, P. and Servais, P. (2000) Measurement of potential activity of fixed nitrifying bacteria in biological filters used in drinking water production. Journal of Industrial Microbiology \& Biotechnology 24(3), 161-166.

Kim, J.G., Jung, M.Y., Park, S.J., Rijpstra, W.I.C., Damste, J.S.S., Madsen, E.L., Min, D., Kim, J.S., Kim, G.J. and Rhee, S.K. (2012) Cultivation of a highly enriched ammonia-oxidizing archaeon of thaumarchaeotal group I.1b from an agricultural soil. Environmental Microbiology 14(6), 1528-1543.

Lane, D.J. (1991) Nucleic acid techniques in bacterial systematics, pp. 115-175, John Wiley and Sons, New York.

Lee, C., Kim, J., Shin, S.G. and Hwang, S. (2006) Absolute and relative QPCR quantification of plasmid copy number in Escherichia coli. Journal of Biotechnology 123(3), 273-280.

Lee, C.O., Boe-Hansen, R., Musovic, S., Smets, B., Albrechtsen, H.J. and Binning, P. (2014) Effects of dynamic operating conditions on nitrification in biological rapid sand filters for drinking water treatment. Water Research 64, 226-236. 
Lopato, L., Rottgers, N., Binning, P.J. and Arvin, E. (2013) Heterogeneous nitrification in a fullscale rapid sand filter treating groundwater. Journal of Environmental Engineering-ASCE 139(3), 375-384.

Madoni, P., Davoli, D., Fontani, N., Cucchi, A. and Rossi, F. (2001) Spatial distribution of microorganisms and measurements of oxygen uptake rate and ammonia uptake rate activity in a drinking water biofilter. Environmental Technology 22(4), 455-462.

Martens-Habbena, W., Berube, P.M., Urakawa, H., de la Torre, J.R. and Stahl, D.A. (2009) Ammonia oxidation kinetics determine niche separation of nitrifying Archaea and Bacteria. Nature 461(7266), 976-979.

Martens-Habbena, W. and Stahl, D.A. (2011) Nitrogen metabolism and kinetics of AmmoniaOxidizing Archaea. Methods in Enzymology 496, 465-487.

Niu, J., Kasuga, I., Kurisu, F., Furumai, H. and Shigeeda, T. (2013) Evaluation of autotrophic growth of ammonia-oxidizers associated with granular activated carbon used for drinking water purification by DNA-stable isotope probing. Water Research 47(19), 7053-7065.

Palomo, A., Fowler, J., Gülay, A., Rasmussen, S., Sicheritz-Ponten, T. and Smets, B.F. (2016) Metagenomic analysis of rapid gravity sand filter microbial communities suggests novel physiology of Nitrospira spp. Accepted for publication in ISME Journal.

Prosser, J.I. (1989) Autotrophic nitrification in bacteria. Advances in Microbial Physiology 30, 125181.

Prosser, J.I. and Nicol, G.W. (2012) Archaeal and bacterial ammonia-oxidisers in soil: the quest for niche specialisation and differentiation. Trends in Microbiology 20(11), 523-531.

Queinnec, I., Ochoa, J.C., Wouwer, A.V. and Paul, E. (2006) Development and calibration of a nitrification PDE model based on experimental data issued from biofilter treating drinking water. Biotechnology and Bioengineering 94(2), 209-222.

Reichert, P. (1998) Aquasim 2.0-User manual. Computer program for identification and simulation of aquatic systems, Swiss Federal Institute for Environmental Science and Technology (EAWAG), CH- Dübendorf, Switzerland.

Ririe, K.M., Rasmussen, R.P. and Wittwer, C.T. (1997) Product differentiation by analysis of DNA melting curves during the polymerase chain reaction. Analytical Biochemistry 245(2), 154160.

Rotthauwe, J.H., Witzel, K.P. and Liesack, W. (1997) The ammonia monooxygenase structural gene amoA as a functional marker: Molecular fine-scale analysis of natural ammonia-oxidizing populations. Applied and Environmental Microbiology 63(12), 4704-4712.

Santoro, A.E. and Casciotti, K.L. (2011) Enrichment and characterization of ammonia-oxidizing archaea from the open ocean: phylogeny, physiology and stable isotope fractionation. ISME Journal 5(11), 1796-1808.

Tatari, K., Smets, B.F. and Albrechtsen, H.J. (2013) A novel bench-scale column assay to investigate site-specific nitrification biokinetics in biological rapid sand filters. Water Research 47(16), 6380-6387. 
Uhl, W. and Gimbel, R. (2000) Dynamic modeling of ammonia removal at low temperatures in drinking water rapid filters. Water Science and Technology 41(4-5), 199-206.

van den Akker, B., Holmes, M., Cromar, N. and Fallowfield, H. (2008) Application of high rate nitrifying trickling filters for potable water treatment. Water Research 42(17), 4514-4524.

van Kessel, M.A.H.J., Speth, D.R., Albertsen, M., Nielsen, P.H., Op den Camp, H.J.M., Kartal, B., Jetten, M.S.M. and Lucker, S. (2015) Complete nitrification by a single microorganism. Nature 528(7583), 555-559.

Wilke, C.R. and Chang, P. (1955) Correlation of diffusion coefficients in dilute solutions. Aiche Journal 1(2), 264-270.

Zhang, Y., Love, N. and Edwards, M. (2009) Nitrification in drinking water systems. Critical Reviews in Environmental Science and Technology 39(3), 153-208. 


\section{Supplementary Information}

\section{Depth investigation of rapid sand filters for drinking water production reveals strong stratification in nitrification biokinetic behavior}

Tatari K.*, Smets B. F. and Albrechtsen H.-J.

Department of Environmental Engineering, Technical University of Denmark, Miljøvej 113, 2800 Kgs. Lyngby, Denmark

*Corresponding author: Tel: +45 45251604, E-mail: kaot@env.dtu.dk (K. Tatari)

Number of pages: 11

Number of tables: 2

Number of figures: 4

\section{Experimental set-up and design of the offline $\mathrm{NH}_{4}^{+}$ removal investigations}

The experimental set-up is illustrated in Figure S1.

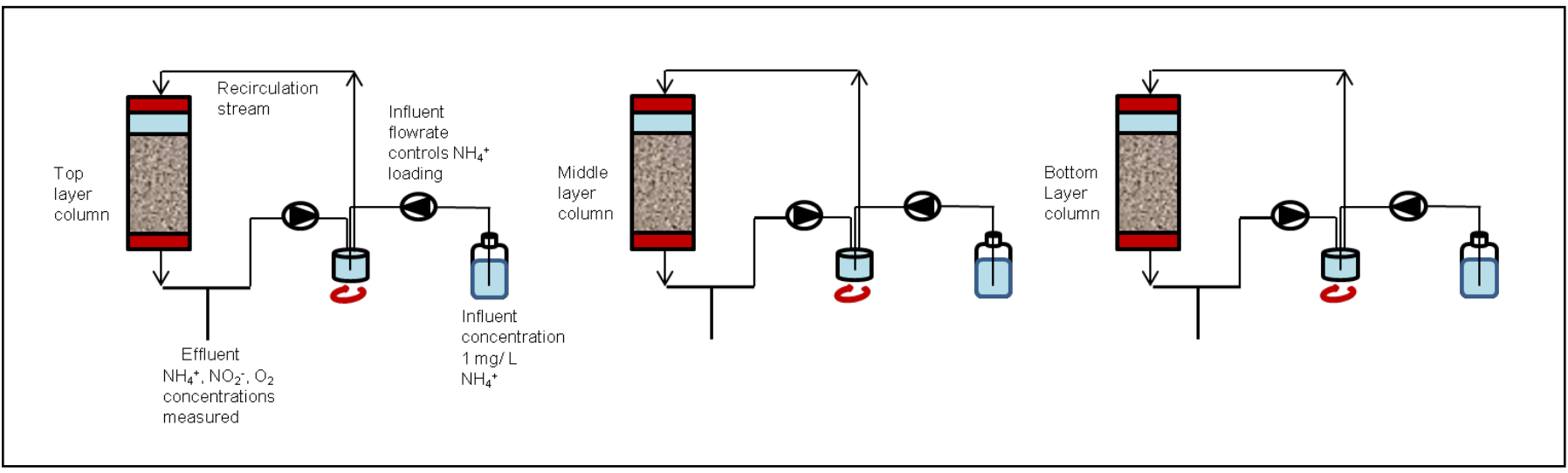

Figure S1. Experimental set-up used for the offline activity experiments. Three columns were operated in parallel, each packed with filter material from the top, middle or bottom layer.

The columns during the offline activity investigations were started-up at reference loading, that equaled $35 \mathrm{~g} \mathrm{NH}_{4}{ }^{+} \mathrm{N} / \mathrm{m}^{3}$ filter material/d. At day 2 of operation, the loading in all three columns 
was up-shifted to $350 \mathrm{~g} \mathrm{NH}_{4}{ }^{+}-\mathrm{N} / \mathrm{m}^{3}$, by increasing the influent flowrate 10 times, while keeping constant the $\mathrm{NH}_{4}{ }^{+}-\mathrm{N}$ influent concentration at $1 \mathrm{mg} / \mathrm{L}$. The up-shifted loading was fed for 3 hours, after which the loading was down-shifted to the reference until the next day. On day 3 of operation, the loading in all columns was up-shifted to $88 \mathrm{~g} \mathrm{NH}_{4}{ }^{-} \mathrm{N} / \mathrm{m}^{3}$, similarly by regulating the influent flowrate and keeping the $\mathrm{NH}_{4}{ }^{+}$influent concentration constant. This up-shift lasted 5 hours, after which the loading was downshifted to the reference. On day 4 of operation, the loading was upshifted to $175 \mathrm{~g} \mathrm{NH}_{4}{ }^{+}-\mathrm{N} / \mathrm{m}^{3}$ for 4 hours, before decreasing the loading back to the reference for the next 5 days. The loading applied to the columns is schematically illustrated in Figure S2. Duration of each loading shift was determined by salt tracer tests, so that both hydraulic and effluent pseudo steady states at the transient conditions could be reached (Tatari et al. 2013).

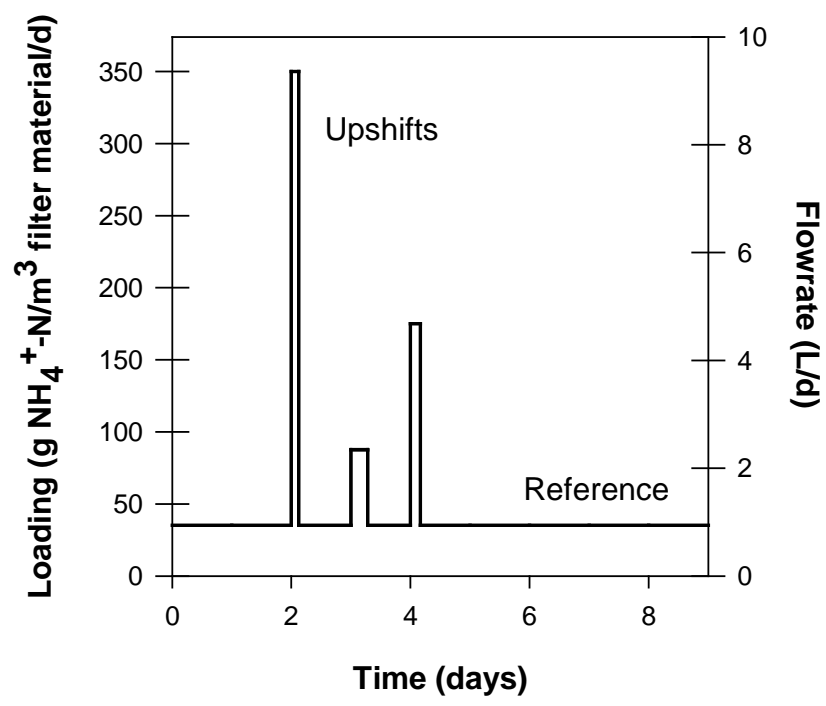

Figure S2. Schematic diagram of the loading applied to each column. Influent $\mathrm{NH}_{4}{ }^{+}$concentration was constant at $1 \mathrm{mg}$ $\mathrm{NH}_{4}{ }^{+}-\mathrm{N} / \mathrm{L}$ and the loading was controlled by adjusting the flowrate.

\section{Calculation of biofilm densities for the model}

To interpret the behavior of the three columns kinetically, a 1-D biofilm model was implemented in Aquasim (Reichert 1998). Each column was modeled independently as a 2 equal volume compartments in series with a total volume of $8.8 \times 10^{-2} \mathrm{~L}$ to match the hydrodynamic behavior characterized by tracer tests (Tatari et al. 2013). The biofilm on the surface of the sand grains was considered homogeneous and continuous.

The initial biofilm thickness $\left(\mathrm{L}_{\mathrm{F}}\right)$ was estimated by confocal laser scanning microscopy (Leica TCS SP5) on sectioned and stained (Syto-9, Invitrogen) grains (Gülay et al. 2014) (Table S1). A known mass of drained-wet filter material was dried at $60^{\circ} \mathrm{C}$ overnight and weighed again to calculate the dry to drained-wet mass conversion factor. The number of grains per mass was manually counted in triplicate samples of 7-16 g dry mass and was converted in grains/drained-wet mass by multiplying with the conversion factor at each depth (Table S1). The particle size distribution was determined by sieving (Vibratory Sieve Shaker AS 200 control, Retsch) of the dry filter material through 2.00$0.063 \mathrm{~mm}$ mesh sized sieves. The median diameter at each depth was determined from the cumulative distribution of the mass fractions retained on each sieve (Table S1). 
Table S1. Experimentally determined physical properties of the filter material at the three investigated depths

\begin{tabular}{|c|c|c|c|}
\hline & Top & Middle & Bottom \\
\hline Median grain radius, $r_{M}(m)^{\dagger}$ & $7 \times 10^{-4}$ & $4 \times 10^{-4}$ & $5 \times 10^{-4}$ \\
\hline Drained-wet packed bulk density, $\rho\left(\mathrm{g} / \mathrm{m}^{3}\right.$ filter material) ${ }^{\ddagger}$ & $1.1 \times 10^{6}$ & $1.6 \times 10^{6}$ & $1.7 \times 10^{6}$ \\
\hline Number of grains per filter material dry mass, $N$ (grains/g) * & 198 & 385 & 382 \\
\hline Initial biofilm thickness, $L_{F}\left(\times 10^{-5}\right)$ & 5.5 & 1 & 1 \\
\hline
\end{tabular}

${ }^{\dagger}$ Particle size distribution determined by sieving of the dry filter material.

${ }^{\ddagger}$ Calculated from the filter material drained-wet mass and volume in a graduated cylinder.

* Manually counted in triplicate.

The total biofilm surface area in each column $A_{F}\left(m^{2}\right)$ was expressed as function of the distance from the biofilm base $\mathrm{z}(\mathrm{m})$ by (Reichert 1998):

$$
\mathrm{A}_{\mathrm{F}}=4 \pi\left(\mathrm{r}_{\mathrm{G}}+\mathrm{z}\right)^{2} \mathrm{~N} \rho \mathrm{V}
$$

where: $r_{G}$ is the radius of the filter material grain without the biofilm $(m), N$ is the number of grains per drained-wet filter material mass (grains/g), $\rho$ is the drained-wet packed bulk density $\left(\mathrm{g} / \mathrm{m}^{3}\right.$ filter material) and $\mathrm{V}$ is the packed filter material volume in the column ( $\mathrm{m}^{3}$ filter material). $\mathrm{r}_{\mathrm{G}}$ was calculated by:

$$
\mathrm{r}_{\mathrm{G}}=\mathrm{r}_{\mathrm{M}}-\mathrm{L}_{\mathrm{F}}
$$

where: $r_{M}$ is the median grain radius estimated from the particle size distribution (m).

The initial volumetric $\mathrm{AOB}$ density $\mathrm{X}_{\mathrm{AOB}, \mathrm{V}}$ (cells $/ \mathrm{m}^{3}$ filter material) determined by molecular tools was converted into COD units for consistency with most modeling studies as follows (IWA task group on biofilm modeling 2006):

$$
\mathrm{X}_{\mathrm{AOB}, \mathrm{V}}^{\mathrm{COD}}=1.42 \times 10^{-12} \mathrm{X}_{\mathrm{AOB}, \mathrm{V}}
$$

where: $\mathrm{X}_{\mathrm{AOB}, \mathrm{V}}^{\mathrm{COD}}$ is the volumetric $\mathrm{AOB}$ density in COD units (g COD $/ \mathrm{m}^{3}$ filter material).

The biofilm volume on a filter material grain was calculated by the volume of a spherical shell of thickness $L_{F}$ on the outer surface of a sphere of radius $r_{G}$. The total biofilm volume $V_{F}\left(\mathrm{~m}^{3}\right.$ biofilm) in a column was:

$$
\mathrm{V}_{\mathrm{F}}=\frac{4}{3} \pi\left(\left(\mathrm{r}_{\mathrm{M}}\right)^{3}-\left(\mathrm{r}_{\mathrm{G}}\right)^{3}\right) \mathrm{N} \rho \mathrm{V} \quad \text { (eq. S4) }
$$

The initial AOB biofilm density $\mathrm{X}_{\mathrm{AOB}, \mathrm{F}}^{\mathrm{COD}}$ in each column (g COD $/ \mathrm{m}^{3}$ biofilm) was calculated as (Wanner and Reichert 1996):

$$
\mathrm{X}_{\mathrm{AOB}, \mathrm{F}}^{\mathrm{COD}}=\frac{\mathrm{X}_{\mathrm{AOB}, \mathrm{V}}^{\mathrm{COD} V}}{\mathrm{~V}_{\mathrm{F}}}
$$




\section{Parameter estimation algorithm}

The parameter estimation algorithm minimized the sum of squares of the weighted deviations between the observed and model predicted values $\chi^{2}(\mathrm{p})$ for each targeted variable $\mathrm{p}$ (effluent $\mathrm{NH}_{4}{ }^{+}$ and $\mathrm{NO}_{2}{ }^{-}$concentration) calculated by ${ }^{1}$ :

$$
\mathrm{x}^{2}(\mathrm{p})=\sum_{\mathrm{i}=1}^{\mathrm{n}}\left(\frac{\mathrm{y}_{\text {meas }, \mathrm{i}}-\mathrm{y}_{\mathrm{i}}(\mathrm{p})}{\sigma_{\text {meas }, \mathrm{i}}}\right)
$$

where: $y_{\text {meas,i }}$ is the $\mathrm{i}$-th experimentally observed value, $\mathrm{y}_{\mathrm{i}}(\mathrm{p})$ is the model predicted value corresponding to the $\mathrm{i}$-th measurement of the variable $\mathrm{p}$ at the time and the location of this measurement, $\sigma_{\text {meas,i }}$ is the standard deviation of the experimental values and $n$ is the number of data points. $\sigma_{\text {meas,i }}$ was determined from triplicate measurements of the same sample and was $0.023 \mathrm{mg}$ $\mathrm{N} / \mathrm{L}$ for $\mathrm{NH}_{4}{ }^{+}$and $0.002 \mathrm{mg} \mathrm{N} / \mathrm{L}$ for $\mathrm{NO}_{2}{ }^{-}$. Three simulations, one for each loading up-shift were created for each column and were run simultaneously, so that parameter estimation fitted the effluent $\mathrm{NH}_{4}{ }^{+}$and $\mathrm{NO}_{2}{ }^{-}$concentrations at these three conditions. Re-calibration of the top and middle layers at reference loading targeted both the $\mathrm{NH}_{4}{ }^{+}$and $\mathrm{NO}_{2}{ }^{-}$effluent concentrations and the final AOB density. The final AOB biofilm density in COD units was calculated from the experimentally determined volumetric densities as above. $\sigma_{\text {meas, }}$ for the final AOB density was calculated from the triplicate qPCR extractions and quantifications of the same sample at each depth. Error contribution of each targeted variable in all parameter estimations is reported in Table S2.

Table S2. Error contribution $\left(\chi^{2}\right)$ of each targeted variable during model calibration at loading up-shifts and during model re-calibration of the top and middle layers at reference loading.

\begin{tabular}{|c|c|c|c|c|}
\hline \multirow[b]{2}{*}{ Loading ( $\mathrm{g} \mathrm{NH}_{4}{ }^{+}-\mathrm{N} / \mathrm{m}^{3}$ filter material $\left./ \mathrm{d}\right)$} & \multicolumn{4}{|c|}{ Top } \\
\hline & $\begin{array}{c}35 \\
\text { (Reference) }\end{array}$ & 88 & 175 & 350 \\
\hline Effluent $\mathrm{NH}_{4}{ }^{+}-\mathrm{N}$ concentration & 11.8 & 1.50 & 39.0 & 93.0 \\
\hline Effluent $\mathrm{NO}_{2}^{-}-\mathrm{N}$ concentration & 487 & 526 & 46.2 & 33.2 \\
\hline Final AOB density & 0.26 & - & - & - \\
\hline \multirow[t]{2}{*}{ Total $\mathrm{x}^{2}$} & $499^{\dagger}$ & - & - & $738^{\ddagger}$ \\
\hline & \multicolumn{4}{|c|}{ Middle } \\
\hline Loading $\left(\mathrm{g} \mathrm{NH}_{4}{ }^{+}-\mathrm{N} / \mathrm{m}^{3}\right.$ filter material/d) & $\begin{array}{c}35 \\
\text { (Reference) }\end{array}$ & 88 & 175 & 350 \\
\hline Effluent $\mathrm{NH}_{4}{ }^{+}-\mathrm{N}$ & 95.8 & 45.1 & 90.5 & 310 \\
\hline Effluent $\mathrm{NO}_{2}^{-}-\mathrm{N}$ & 204 & 30.3 & 70.3 & 291 \\
\hline Final AOB density & 14.3 & - & - & - \\
\hline Total $\mathrm{x}^{2}$ & $314^{\dagger}$ & - & - & $837^{\ddagger}$ \\
\hline
\end{tabular}




\begin{tabular}{l|cccc}
\hline & \multicolumn{4}{|c}{ Bottom } \\
\cline { 2 - 5 } Loading $\left(\mathrm{g} \mathrm{NH}_{4}{ }^{+}-\mathrm{N} / \mathrm{m}^{3}\right.$ filter material/d) & $\begin{array}{c}\mathbf{3 5} \\
\text { (Reference) }\end{array}$ & $\mathbf{8 8}$ & $\mathbf{1 7 5}$ & $\mathbf{3 5 0}$ \\
\hline Effluent $\mathrm{NH}_{4}{ }^{+}-\mathrm{N}$ & - & 275 & 900 & 421 \\
Effluent $\mathrm{NO}_{2}{ }^{-}-\mathrm{N}$ & - & 205 & 100 & 258 \\
Final AOB density & - & - & - & - \\
Total $\mathrm{X}^{2}$ & - & - & - & $2159^{\ddagger}{ }^{\dagger}{ }^{+}$ \\
\hline
\end{tabular}

$\mathrm{X}^{2}$ error contribution from all three targeted variables (effluent $\mathrm{NH}_{4}{ }^{+}$and $\mathrm{NO}_{2}{ }^{-}$effluent concentrations and final $\mathrm{AOB}$ density) at reference loading.

${ }^{\ddagger}$ Total $X^{2}$ error contribution of the two targeted variables (effluent $\mathrm{NH}_{4}{ }^{+}$and $\mathrm{NO}_{2}{ }^{-}$effluent concentrations) at all three loading up-shifts.

\section{Sensitivity analysis}

Local sensitivity analysis was conducted at reference loading to evaluate model sensitivity to eventual changes or uncertainty in the biofilm properties and kinetic parameters. The local sensitivity analysis extrapolated linearly the effect on model output due to change in one parameter each time within a defined range of uncertainty ${ }^{2}$. An absolute-relative sensitivity measure $\delta$ was calculated by ${ }^{1}$ :

$$
\delta=p \frac{\partial y}{\partial p}
$$

where: $y$ is the output variable examined for sensitivity (in this case the effluent $\mathrm{NH}_{4}{ }^{+}$or $\mathrm{NO}_{2}{ }^{-}$ concentrations) and $\mathrm{p}$ is the input variable that is allowed to vary each time. The $\delta$ sensitivity measure indicates the absolute change in the y output variable value caused by a $100 \%$ change in the $\mathrm{p}$ input variable value. Large $\delta$ means that the parameter $\mathrm{p}$ has a substantial effect on the considered model output. Positive $\delta$ values indicate a positive effect on the y output variable value, whereas negative $\delta$ values indicate a negative effect on the y output variable value.

All model parameters were included in the sensitivity analysis, and were ranked according to their effect on the predicted effluent $\mathrm{NH}_{4}{ }^{+}$or $\mathrm{NO}_{2}{ }^{-}$concentration. Figures S3 and S4 illustrate the first 18 parameters in the ranking i.e. the ones whose change had the greatest impact on the model output. 

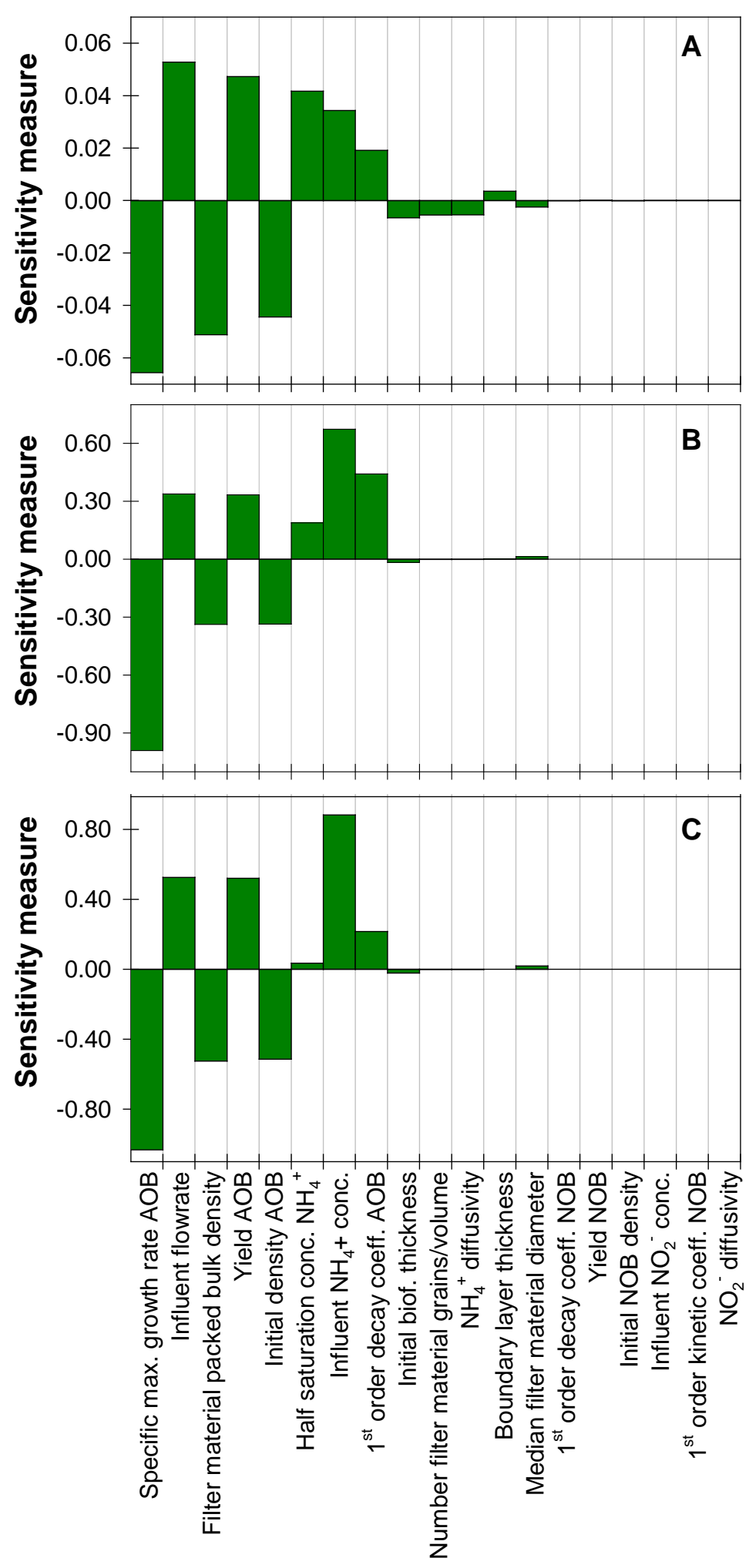

Figure S3. Sensitivity measure of input model parameters on the predicted effluent $\mathrm{NH}_{4}{ }^{+}$concentration at reference loading (35 $\mathrm{g} \mathrm{NH}_{4}{ }^{+}-\mathrm{N} / \mathrm{m}^{3}$ filter material/d) in top (A), middle (B) and bottom (C) layer columns. 


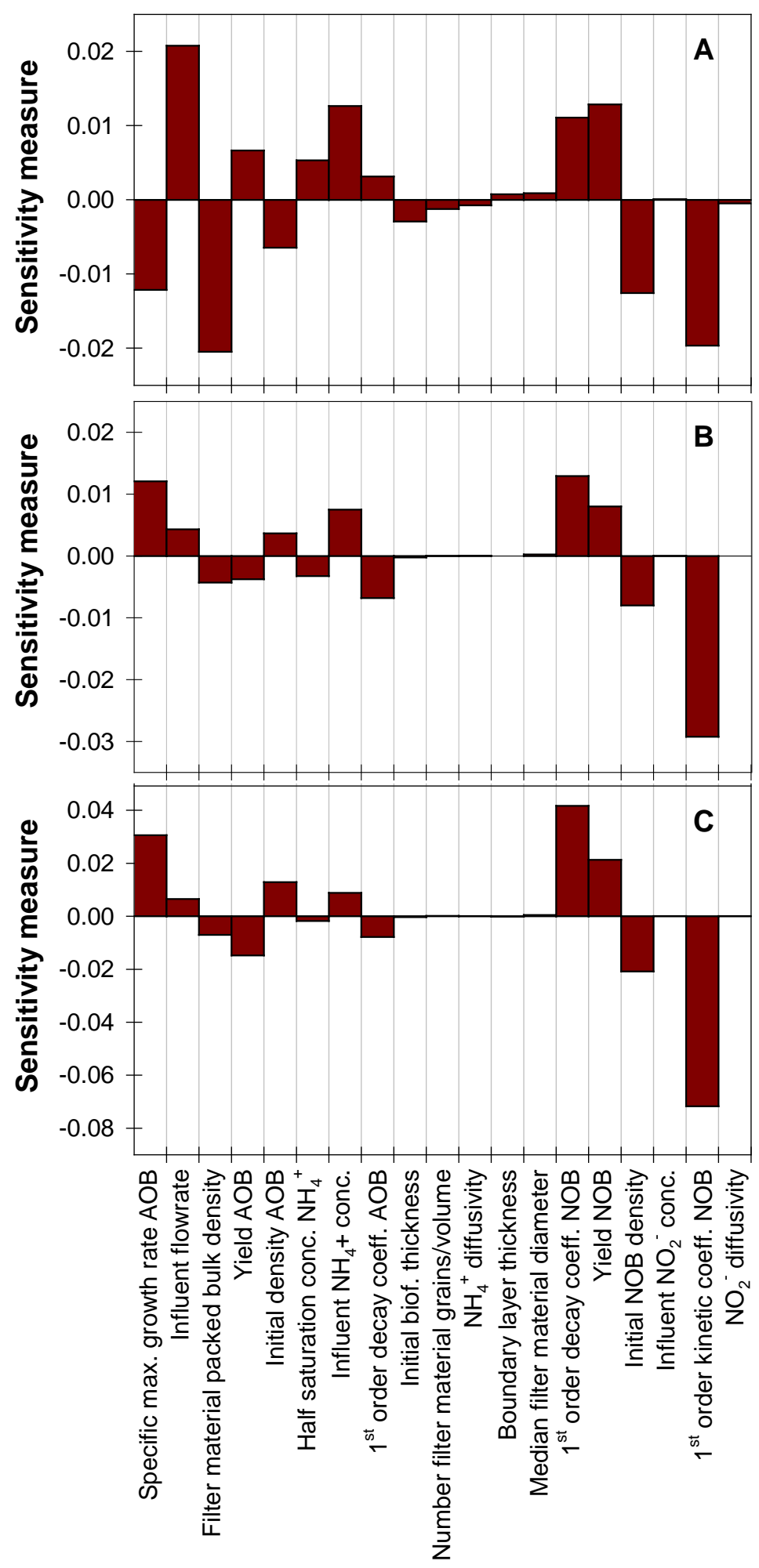

Figure S4. Sensitivity measure of input model parameters on the predicted effluent $\mathrm{NO}_{2}{ }^{-}$concentration at reference loading (35 $\mathrm{g} \mathrm{NH}_{4}{ }^{+}-\mathrm{N} / \mathrm{m}^{3}$ filter material/d) in top (A), middle (B) and bottom (C) layer columns. 


\section{Evaluation of mass transfer limitations}

To exclude that $\mathrm{NH}_{4}{ }^{+}$removal in the columns was limited by external mass transfer, we calculated the relative ratio $\mathrm{K}^{*}$ of the $\mathrm{NH}_{4}{ }^{+}$external transport and the maximum $\mathrm{NH}_{4}{ }^{+}$utilization and diffusion rate in the biofilm (Rittmann and McCarty 2001):

$$
\text { VI. } \quad \mathrm{K}^{*}=\frac{\mathrm{D}_{\mathrm{W}}}{\mathrm{L}_{\mathrm{L}}}\left[\frac{\mathrm{K}_{\mathrm{S}}}{\mathrm{q}_{\max } \mathrm{X}_{\mathrm{AOB}, \mathrm{F}}^{\mathrm{COD}} \mathrm{D}_{\mathrm{F}}}\right]^{1 / 2}
$$

where: $\mathrm{D}_{\mathrm{W}}$ is the $\mathrm{NH}_{4}{ }^{+}$diffusivity in water at $10^{\circ} \mathrm{C}\left(\mathrm{m}^{2} / \mathrm{d}\right), \mathrm{L}_{\mathrm{L}}$ is the calculated external boundary layer thickness $(\mathrm{m}), \mathrm{X}_{\mathrm{AOB}, \mathrm{F}}^{\mathrm{COD}}$ is the $\mathrm{AOB}$ density expressed in COD units per unit biofilm volume as calculated in eq. S1-S5 in SI, and $\mathrm{D}_{\mathrm{F}}$ is the $\mathrm{NH}_{4}{ }^{+}$diffusivity in the biofilm ( $\left.\mathrm{m}^{2} / \mathrm{d}\right)$. $\mathrm{K}^{*}$ values below 1 indicate slow external transport and therefore potential limitation by mass transfer. Calculated $\mathrm{K}^{*}$ values for the three columns ranged at reference loading from 11 to 28 and at loading up-shifts from 10 to 15 , hence external mass transfer was not rate limiting. This conclusion was consistent with the model predicted $\mathrm{NH}_{4}{ }^{+}$and $\mathrm{NO}_{2}{ }^{-}$spatial concentration profiles at selected time points, which showed a maximum of $14 \%$ decrease between the $\mathrm{NH}_{4}{ }^{+}$ concentration in the bulk and at the biofilm base (data not shown). This indicates that internal biofilm diffusion was also not limiting $\mathrm{NH}_{4}{ }^{+}$removal. This conclusion based on kinetic analysis is consistent with the experimental observations from Lee et al. (2014), who observed that the pilot filter removal was only determined by the loading and not the flowrate. Other studies however support that mass transfer can limit removal in these filters (Lopato et al. 2013, Stembal et al. 2005, van den Akker et al. 2008)

\section{Calculated cell specific $\mathrm{NH}_{4}{ }^{+}$removal rates for the examined microbial types}

To examine whether other microbial types than AOB, and particularly AOA could be the dominant $\mathrm{NH}_{4}{ }^{+}$oxidizers, we calculated what their cell specific $\mathrm{NH}_{4}{ }^{+}$removal rates would be at reference loading. Since the densities of these microbial types did not change consistently during the column experiments, the observed $\mathrm{NH}_{4}{ }^{+}$removal rates were normalized with the average of the initial and final microbial densities. Resulting cell specific $\mathrm{NH}_{4}{ }^{+}$removal rates are illustrated in Figure S5.

The calculated cell specific $\mathrm{NH}_{4}{ }^{+}$removal rates for AOA ranged within $1.3-17.4 \times 10^{5} \mathrm{fg} \mathrm{NH}_{4}{ }^{+}$N/cell/d (Figure S4), which is roughly 4 orders of magnitude higher than most reported literature values ranging within 28-192 $\mathrm{fg} \mathrm{NH}_{4}{ }^{+}-\mathrm{N} / \mathrm{cell} / \mathrm{d}$ (Kim et al. 2012, Prosser and Nicol 2012, Santoro and Casciotti 2011), ultimately suggesting that AOA should not be the predominant active nitrifiers at the given conditions. However, Kasuga et al. 2010 reports extremely high AOA cell specific $\mathrm{NH}_{4}{ }^{+}$removal rates ranging within $1.4-24 \times 10^{4} \mathrm{fg} \mathrm{NH}_{4}{ }^{+}-\mathrm{N} /$ cell/d from an activated carbon filter where AOA appeared to be the predominant nitrifiers. 




Figure S5. $\mathrm{NH}_{4}{ }^{+}$removal rates at reference loading normalized by the number of cells for each investigated microbial type in the three columns. The average of the initial and final microbial densities was used for the normalization.

\section{Full scale filter depth profiles}

The full scale filter $\mathrm{NH}_{4}{ }^{+}$depth profile was obtained by sampling water in the 0.05-0.40 m interval during 6 sampling campaigns conducted over 2 filter-run cycles is illustrated in Figure S6.

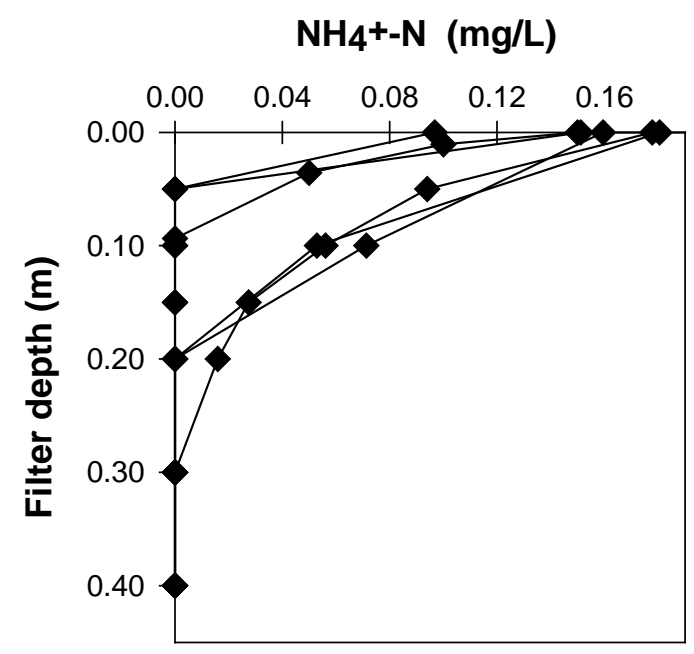

Figure S6. $\mathrm{NH}_{4}{ }^{+}$depth profiles obtained over two filtering cycles in the investigated filter at Islevbro waterworks.

\section{Predicting filter performance based on depth-specific nitrification capacities}

The measured depth-specific nitrification capacities were used to predict full-scale filter performance at increased loading rates. The depth needed to remove the influent loading to below guideline limits was calculated for a 10-fold loading increase, examined for two scenarios: concentration and flowrate increase. In both scenarios the filter was assumed to be $0.50 \mathrm{~m}$ deep, as the deepest $0.2 \mathrm{~m}$ of the filter were not investigated due to sampling limitations. The $0.5 \mathrm{~m}$ deep 
filter bed was divided into three sections: top $(0-0.10 \mathrm{~m})$, middle $(0.10-0.30 \mathrm{~m})$ and bottom $(0.30$ $0.50 \mathrm{~m}$ ), to include all intermediate depths that were not investigated in the lab-scale assays. Maximum removal from these filter sections was considered equal to the experimentally estimated nitrification capacity of the respective layer. Based on mass balance the concentration in the top section was calculated by:

$$
\mathrm{S}_{\mathrm{top}, \mathrm{x}}=\frac{\mathrm{S}_{\text {in }} \mathrm{Q}-10^{3} \mathrm{r}_{\text {max }, \text { top }} \times \mathrm{A}_{\mathrm{F}}}{\mathrm{Q}}
$$

where: $\mathrm{x}$ is the vertical coordinate reflecting the depth within the top section $(0 \leq \mathrm{x} \leq 0.1 \mathrm{~m}), \mathrm{S}_{\text {top, } \mathrm{x}}$ is the $\mathrm{NH}_{4}{ }^{+}$concentration at a depth $\mathrm{x}(\mathrm{mg} \mathrm{N} / \mathrm{L}), \mathrm{S}_{\mathrm{in}}$ is the influent $\mathrm{NH}_{4}{ }^{+}$concentration $(\mathrm{mg} \mathrm{N} / \mathrm{L}), \mathrm{Q}$ is the flowrate $(\mathrm{L} / \mathrm{d}), \mathrm{A}_{\mathrm{F}}$ is the cross sectional area of the filter $\left(\mathrm{m}^{2}\right)$, and $r_{\text {max,top }}$ is the nitrification capacity of the top filter layer $\left(\mathrm{g} \mathrm{NH}_{4}{ }^{+}-\mathrm{N} / \mathrm{m}^{3}\right.$ filter material/d). Similarly, the concentration in the middle section was calculated by:

$$
S_{\text {mid,y }}=\frac{S_{\text {in }} \mathrm{Q}-10^{3}\left(r_{\text {max }, \text { top }} V_{\text {top }, 0.1}+r_{\text {max }, \text { mid }} \mathrm{y} A_{F}\right)}{Q}
$$

where: $\mathrm{y}$ is the vertical coordinate reflecting the depth within the middle section $(0 \leq \mathrm{y} \leq 0.2 \mathrm{~m})$, $\mathrm{S}_{\text {mid, y }}$ is the $\mathrm{NH}_{4}{ }^{+}$concentration at a coordinate y (mg N/L), equivalent to a $\mathrm{y}+0.1 \mathrm{~m}$ depth in the filter, $\mathrm{r}_{\text {max,mid }}$ is the nitrification capacity of the middle layer $\left(\mathrm{g} \mathrm{NH}_{4}{ }^{+}-\mathrm{N} / \mathrm{m}^{3}\right.$ filter material/d), and $\mathrm{V}_{\text {top, } 0.1}$ is the volume of the entire top section $(\mathrm{x}=0.1 \mathrm{~m})$. Lastly, the concentration in the bottom section was calculated by:

$$
\mathrm{S}_{\mathrm{bot}, \mathrm{z}}=\frac{\mathrm{S}_{\mathrm{in}} \mathrm{Q}-10^{3}\left(\mathrm{r}_{\mathrm{max}, \mathrm{top}} \mathrm{V}_{\text {top }, 0.1}+\mathrm{r}_{\mathrm{max}, \mathrm{mid}} \mathrm{V}_{\text {mid }, 0.2}+\mathrm{r}_{\mathrm{max}, \mathrm{bot}} \mathrm{z} \mathrm{A}_{\mathrm{F}}\right)}{\mathrm{Q}}
$$

where: $\mathrm{z}$ is the vertical coordinate reflecting the depth within the bottom section $(0 \leq \mathrm{z} \leq 0.2 \mathrm{~m})$, $\mathrm{S}_{\text {bot, } \mathrm{z}}$ is the concentration at a coordinate $\mathrm{z}(\mathrm{mg} \mathrm{N} / \mathrm{L})$, equivalent to a $0.3+\mathrm{z} \mathrm{m}$ depth in the filter, $\mathrm{r}_{\text {max,bot }}$ is the nitrification capacity of the bottom layer $\left(\mathrm{g} \mathrm{NH}_{4}{ }^{+}-\mathrm{N} / \mathrm{m}^{3}\right.$ filter material/d), and $\mathrm{V}_{\text {mid, } 0.2}$ is the volume of the entire middle section $(y=0.2 \mathrm{~m})$.

For the increasing concentration scenario, $S_{\text {in }}$ was given values from 0.13 to $1.3 \mathrm{mg} \mathrm{NH}{ }_{4}{ }^{-} \mathrm{N} / \mathrm{L}$ at a $0.001 \mathrm{mg} / \mathrm{L}$ step size, while $\mathrm{Q}$ was constant at $1.73 \times 10^{6} \mathrm{~L} / \mathrm{d}$. For the increasing flowrate scenario, $\mathrm{Q}$ was given values from $1.73 \times 10^{6} \mathrm{~L} / \mathrm{d}$ to $17.3 \times 10^{6} \mathrm{~L} / \mathrm{d}$ at a $24 \mathrm{~L} / \mathrm{d}$ step size, while $\mathrm{S}_{\text {in }}$ remained constant at $0.13 \mathrm{mg} \mathrm{NH}_{4}{ }^{+}-\mathrm{N} / \mathrm{L}$. The calculation algorithms for both scenarios were implemented in MATLAB, and the minimum depth so that the $\mathrm{NH}_{4}{ }^{+}$concentration is below strict guideline limits $\left(0.05 \mathrm{mg} \mathrm{NH}_{4} / \mathrm{L}\right)$ was identified.

The calculated effluent concentrations at both scenarios as well as the concentration at 0.1 and 0.3 m depth are illustrated in Figure S7. 


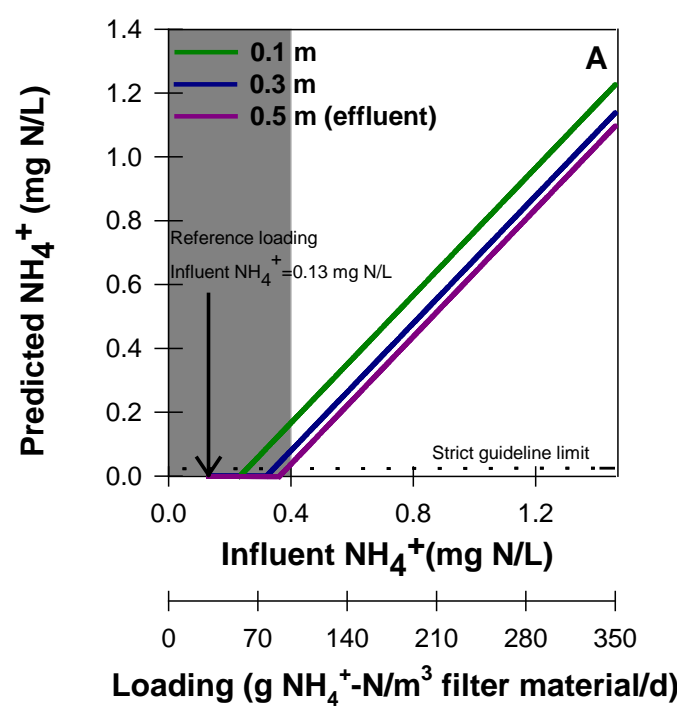

Figure S7. Predicted $\mathrm{NH}_{4}{ }^{+}$effluent and concentration at selected filter depths for loadings ranging from the reference ( $35 \mathrm{~g}$ $\mathrm{NH}_{4}{ }^{+}-\mathrm{N} / \mathrm{m}^{3}$ filter material/d) to $350 \mathrm{~g}$ $\mathrm{NH}_{4}{ }^{+}-\mathrm{N} / \mathrm{m}^{3}$ filter material/d. Loading was increased by: (A) increasing the influent concentration from 0.13 to $1.3 \mathrm{mg} \mathrm{NH}_{4}{ }^{+}$ $\mathrm{N} / \mathrm{L}$ keeping the flowrate constant at $1.73 \times 10^{6} \mathrm{~L} / \mathrm{d}$, (B) increasing the flowrate from $1.73 \times 10^{6} \mathrm{~L} / \mathrm{d}$ to $17.3 \times 10^{6} \mathrm{~L} / \mathrm{d}$ keeping the influent concentration constant at 0.13 mg $\mathrm{NH}_{4}{ }^{+}$-N/L. The shaded areas correspond to the safe operational loading windows if a strict guideline limit of 0.05 mg $\mathrm{NH}_{4}^{+} / \mathrm{L}$

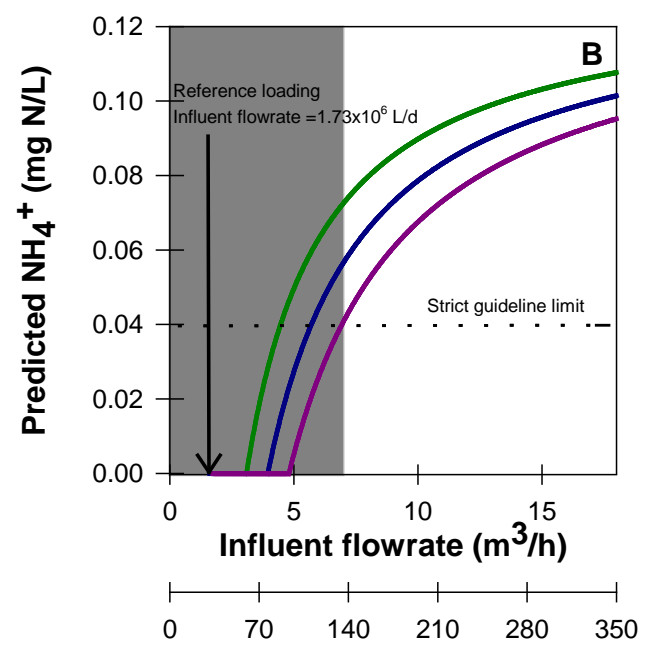

Loading ( $\mathrm{g} \mathrm{NH}_{4}^{+}-\mathrm{N} / \mathrm{m}^{3}$ filter material/d)

\section{References}

Boltz, J.P., Morgenroth, E., Brockmann, D., Daigger, G.T., Henze, M., Rittmann, B., Sørensen, K.H., Takács, I., Vanrolleghem, P.A. and van Loosdrecht, M. (2013) A biofilm reactor model calibration framework. 9th International Conference on Biofilm Reactors, Paris.

Eberl, H., Morgenroth, E., Noguera, D., Picioreanu, C., Rittmann, B., Van Loodsdrecht, M. and Wanner, O. (2006) Mathematical modeling of biofilms, pp. 11-41, IWA publishing, London

Gülay, A., Tatari, K., Musovic, S., Mateiu, R.V., Albrechtsen, H.-J. and Smets, B.F. (2014) Internal porosity of mineral coating supports microbial activity in rapid sand filters for groundwater treatment. Applied and Environmental Microbiology 80(22), 7010-7020.

Kasuga, I., Nakagaki, H., Kurisu, F. and Furumai, H. (2010) Predominance of ammonia-oxidizing archaea on granular activated carbon used in a full-scale advanced drinking water treatment plant. 
Water Research 44(17), 5039-5049.

Kim, J.G., Jung, M.Y., Park, S.J., Rijpstra, W.I.C., Damste, J.S.S., Madsen, E.L., Min, D., Kim, J.S., Kim, G.J. and Rhee, S.K. (2012) Cultivation of a highly enriched ammonia-oxidizing archaeon of thaumarchaeotal group I.1b from an agricultural soil. Environmental Microbiology 14(6), 15281543.

Lee, C.O., Boe-Hansen, R., Musovic, S., Smets, B., Albrechtsen, H.J. and Binning, P. (2014) Effects of dynamic operating conditions on nitrification in biological rapid sand filters for drinking water treatment. Water Research 64, 226-236.

Lopato, L., Rottgers, N., Binning, P.J. and Arvin, E. (2013) Heterogeneous nitrification in a fullscale rapid sand filter treating groundwater. Journal of Environmental Engineering-Asce 139(3), 375-384.

Prosser, J.I. and Nicol, G.W. (2012) Archaeal and bacterial ammonia-oxidisers in soil: the quest for niche specialisation and differentiation. Trends in Microbiology 20(11), 523-531.

Reichert, P. (1998) Aquasim 2.0-User manual. Computer program for identification and simulation of aquatic systems, Swiss Federal Institute for Environmental Science and Technology (EAWAG), CH- Dübendorf, Switzerland.

Rittmann, B. and McCarty, P. (2001) Environmental Biotechnology:Principles and Applications. McGraw-Hill, 215-220.

Santoro, A.E. and Casciotti, K.L. (2011) Enrichment and characterization of ammonia-oxidizing archaea from the open ocean: phylogeny, physiology and stable isotope fractionation. Isme Journal 5(11), 1796-1808.

Stembal, T., Markic, M., Ribicic, N., Briski, F. and Sipos, L. (2005) Removal of ammonia, iron and manganese from groundwaters of northern Croatia - pilot plant studies. Process Biochemistry 40(1), 327-335.

Tatari, K., Smets, B.F. and Albrechtsen, H.J. (2013) A novel bench-scale column assay to investigate site-specific nitrification biokinetics in biological rapid sand filters. Water Research 47(16), 6380-6387.

van den Akker, B., Holmes, M., Cromar, N. and Fallowfield, H. (2008) Application of high rate nitrifying trickling filters for potable water treatment. Water Research 42(17), 4514-4524.

Wanner, O. and Reichert, P. (1996) Mathematical modeling of mixed-culture biofilms. Biotechnology and Bioengineering 49(2), 172-184. 